\title{
The effect of politician-constituent conflict on bureaucratic responsiveness under varying information frames
}

\author{
Annabelle S. Wittels*
}

Last updated: December 2020

\begin{abstract}
With whom bureaucrats side has consequences for the efficacy of participatory governance processes. Participatory governance claims to "deepen" democracy by offering citizens opportunities to express policy preferences throughout the electoral cycle. When citizen input derived from participatory governance initiatives is at odds with the orders of politicians in power, (i) do bureaucrats side with political principals as most political economy accounts would predict, (ii) do they shape policy as the bureau-shaping hypothesis proposes, (iii) or is their reaction much more ad-hoc and driven by behavioural biases as theories of representative democracy and behavioural public administration would predict? This study assesses this using a survey experiment with bureaucrats with managerial responsibilities, employed in the UK and US public sector. It finds that when citizen input and demands of political principals are at logger-heads, bureaucrats behave in line with the bureau-shaping hypothesis - they will shape policy design according to their professional norms and values. There is no evidence that they react to differences in how the information is framed, speaking against purely behavioural interpretation.
\end{abstract}

*annabelle.wittels@eui.eu 
Bureaucrats are political actors in their own right - within the constraints of organisational hierarchies and electoral institutions. Classical political economy accounts of bureaucrats expect them to maximise their self-interest, but ultimately yield to the power of political principals where their resources and discretion over policy is limited (Banks and Weingast, 1992; Ting, 2001; Prendergast, 2007; Moe, 2006, 2012; Butler and Arceneaux, 2015). More empirically driven work however illustrate that policy-making amounts to a co-production between politicians and bureaucrats Aberbach and Rockman, 1994; Page, 2012; Baekgaard et al., 2015a b; Blom-Hansen, Baekgaard, and Serritzlew, Blom-Hansen et al.; Baekgaard and Serritzlew, 2020). Whether bureaucrats align with demands of politicians depends on the issue salience of the policy in question (Baekgaard et al. 2015b), professional norms (Page, 2012; Andersen and Jakobsen, 2016) and institutional incentives (Gains et al., 2008; Gains and John, 2010). With whom bureaucrats side has distributional consequences. This is especially well documented for so-called street-level bureaucrats (Lipsky, 1983), bureaucrats who work in citizen-facing roles and frontline services such as welfare claim processing (Lipsky, 1983; Scott, 1997; Keiser, 2010), the police (Nicholson-Crotty and O'Toole, 2004), fire services Andrews et al., 2014) or teachers (Keiser et al., 2002). It is however much less clear how bureaucrats react in the context of participatory governance.

Participatory governance initiatives are government initiated. Citizens are asked to express their opinions on a defined and - compared to election manifestos - more immediate set of policy actions. They present a more top- 
down form of participation than other forms of citizen engagement such as participation in social movements. These constraints render citizens dependent on faithful management of their input.

Governments expend considerable effort and resources to run participatory processes (OECD, 2009; Speer, 2012). Yet, it remains largely unclear to what extent such processes deliver on their promise.

Participatory governance is an area that affords special attention as it claims to 'deepen' democracy by: (i) offering citizens opportunities to express policy preferences throughout the electoral cycle, in a more direct manner than through delegation to politicians, and (ii) by awarding democratic legitimacy to citizen groups trying to affect policy - setting it apart from contested channels such as lobbying.

In many instances, participatory mechanisms can amount to window dressing on behalf of politicians (Batory and Svensson, 2019) and bureaucrats (Migchelbrink and Van De Walle, 2020) alike. Politicians can design consultations in such a manner that they provide the answers they need, while bureaucrats can proportion their efforts in managing participatory governance processes in a way that increases or decreases the legitimacy of citizen input. It is thus of paramount importance to an assessment of the validity and efficacy of participatory governance processes to understand how the interaction between bureaucrats and their political principals affects the likelihood of citizens to influence policy decisions. In a situation where citizen input derived from participatory governance initiatives is at odd with the orders of 
politicians in power, (i) do bureaucrats side with their political principals as most political economy accounts would predict?; (ii) do they fight to shape policy as the bureau-shaping hypothesis (Gains and John, 2010) proposes?; (iii) or is their reaction much more ad-hoc and driven by behavioural biases as theories of representative democracy and behavioural public administration would predict? This study set out to test this using a survey experiment with bureaucrats with managerial responsibilities, employed in the UK and US public sector.

It finds that when citizen input and demands of political principals are in conflict, bureaucrats behave in line with the bureau-shaping hypothesis - they will go to extra lengths to shape policy design according to their professional norms and values. There is no evidence that they react to differences in how the information is framed, making a purely behavioural interpretation unlikely. Street-level bureaucrats are less likely to side with citizens and more likely to use their discretion. Such use of discretion is in line with literature on street-level bureaucracy but rarely contrasted with behaviour of non-street level bureaucrats.

Qualitative evidence suggests that the underlying mechanism for this is that street-level bureaucrats strongly hold the perception that they are more informed than the citizens they serve and or act upon "what they intuitively know is right". This finding has implications for theories of representative democracy and propositions put forward by behavioural public policy. Professional socialisation appears to matter more to responsiveness than ad-hoc 
behavioural biases. If street-level bureaucrats indeed act more based on their own value systems and subjective perceptions, achieving a greater match in the socio-demographic composition of the street-level bureaucracy and the citizens they serve (e.g. police and residents of neighbourhoods that are policed) is of even greater importance than achieving such a balance in more centralised functions of the government bureaucracy.

The paper proceeds by providing a short introduction to the role of bureaucrats in participatory governance processes and how theories of bureaucrat behaviour and bias relate to this. It then explains the survey experiment. The paper concludes with a discussion of implications for three sets of theories: principal-agent theory, the budget-shaping hypothesis and representative bureaucracy.

\section{Participatory governance and the role of bu-}

\section{reaucrats}

Participatory governance affords important gate-keeping powers to bureaucrats. As a top-down form of participation, citizens are dependent on faithful handling of their information to reach key decision-makers; this is different to other forms of non-electoral participation such protests. While the literature on participatory governance claims that it can strengthen democratic norms (Fung, Archon; Wright, 2001; Fishkin, 2018), norms about how to perceive and handle inputs derived from participatory governance processes are much 
less well established. Most participatory governance processes are purposely designed to be legally non-binding or limited in their scope. If one sees participatory processes on a continuum from low to high power, participatory budgeting falls within the high power end of the spectrum:

it produces decisions that can shift (local) government budgets and thus affect distributional wealth much more directly than many other forms of political participation. Yet, most operational participatory budgeting processes limit the amount or share of the budget which is open to a vote. 1 Less direct, albeit more ubiquitous (OECD, 2009), forms of participatory governance such as citizen consultations, surveys, online discussion fora and town hall debates, offer much less direct control. The efficacy of the process is highly dependent on interpretations of the elites who handle this information.

For one, politicians can (ab)use participatory governance processes for window dressing - they shape them so they get the answers they desire $\mathrm{Ba}-$ tory and Svensson, 2019). Bureaucrats can act as a bulwark against such populist tendencies by insisting on due process and holding a citizen-orientation (Miller et al., 2017). However, what bureaucrats judge as "legitimate" or "representative" input is still subjective (Migchelbrink and Van De Walle, 2020) $2^{2}$

\footnotetext{
${ }^{1}$ For instance, this is the case for the budget of the city of Paris, France, and in many settings in Brazil, where the concept was first popularised. Often sub-budgets such as education or water management are opened to participation, while others remain closed off.

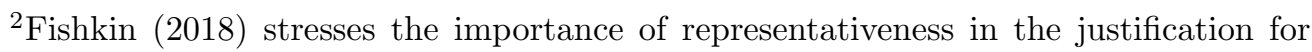
involving the public In the case of Fishkin (2018)'s work, so-called mini-publics, randomly drawn samples of the public who are invited to deliberate on policy choices.. Such
} 
In how bureaucrats present evidence to politicians (Blom-Hansen, Baekgaard, and Serritzlew, Blom-Hansen et al.) - for instance as legitimate or not - bureaucrats can heighten or dampen the impact of citizen input. This is particularly true for policy areas where low issue salience or low levels of political expertise leave greater discretion for bureaucrats to shape policy (Page, 2012)

\section{Theories of bureaucrat behaviour under con- flict}

Three theories can broadly explain how we should expect bureaucrats to handle input from citizens as part of a participatory process: classical principalagent theory, the bureau-shaping hypothesis and behavioural public administration theories.

\section{Classical principal-agent models}

Classical principal-agent models suggest that under conflict, bureaucrats will side with politicians $($ Page, 2012). Even when formal controls on their behaviour leave room for discretion (Gailmard and Patty, 2012), the career prospects and job security of bureaucrats can be endangered when they decide to confront their political prinicpals. This is - perhaps more well known representativeness goes beyond statistical considerations of sample size and demographic spread. 
- the case for countries where patronage networks prevail (Cruz and Keefer, 2015; Enikolopov, 2014; Meyer-Sahling et al., 2018; Colonelli et al., 2018), but can also occur in Western administrations. Several studies illustrate how bureaucrats actively develop political entrepreneurship as a skill to appear in a good light in front of their political principals (Page, 2012, Baekgaard et al., 2020). When the demands of the citizen groups bureaucrats are mandated to serve and those of their political principals are at odds, such models would predict that bureaucrats discount information from citizens in favour of that provided by their political principals.

The risk of sanction, prominently covered in the classical literature on political control (Banks and Weingast, 1992; Ting, 2001; Prendergast, 2007; Moe, 2006, 2012; Butler and Arceneaux, 2015), should motivate bureaucrats to comply. The magnitude in response is likely to vary with the bureaucrat's risk preferences, but bureaucrats can be expected to generally perceive the threat of sanction to be larger when acting counter to the demands of politicians than when acting against those of citizens. This can be expected for a number of reasons: For one, politicians can sanction bureaucrats more directly and immediately than citizens. They can create and close agencies, set budgets, change salary levels, contractual terms and powers that agencies are granted. Politicians can thus affect the number, security and attractiveness of public sector jobs. In country contexts where patronage prevails, the careers of bureaucrats can be affected even more directly (Cruz and Keefer, 2015; Enikolopov, 2014; Meyer-Sahling et al., 2018). 
Citizens too can sanction bureaucrats' behaviour but need to rely largely on mobilising the legislature or judiciary to act on their behalf. For instance, Bertelli and John (2010) show that citizens' performance ratings of local government services affect their budgets in the subsequent period as central government responds to these performance ratings. Evidently however such sanctions are mediated and likely temporally more delayed compared to those of politicians. This implies that bureaucrats should perceive there to be a greater risk of immediate sanction from their political compared to citizen principals. The expectation thus is that bureaucrats will yield more to politicians when demands are conflicting because negating politicians' demands comes at a greater cost than ignoring citizen input.

\section{Bureau-shaping hypothesis}

The bureau-shaping hypothesis offers a more value-driven account of bureaucrat behaviour. Bureaucrats in central planning and senior roles from European as well as US administrations have reported that their daily work can veer into the political (Alford et al. 2017) and that neutrality is aspired to but rarely enforced in practice Adolph, 2013; Hustedt and Salomonsen, 2014). The political influence of bureaucrats becomes especially salient when politicians diverge from public opinion, or in the context of this study, from the opinions brought forward by public participation processes.

Politicians have been shown to be generally responsive to their constituents (Fox and Shotts, 2009; Rottinghaus, 2015, Costa, 2017), yet not on 
all issues nor for all constituent groups Newman and Griffin, 2005, Costa, 2017; Emeriau, 2019). There is room for bureaucrats to influence politicians to shift their position closer to that of the citizenry or divert from it. Results of inter-electoral public participation mechanisms are not legally binding in most countries and contexts. For example, in the US, the government and most agencies have a legal duty to circulate new orders for public comment before they are adopted. Yet, there are no prescriptions on how they have to respond to them. Similarly, in the UK, it is left to the discretion of the government and agencies to determine whether and how to respond.

According to the bureau-shaping hypothesis, the bureaucracy is a cadre of highly educated and - in many instances - highly professionalised individuals. They do not only opt into these occupations because of a desire to serve the public (Esteve et al., 2017) but also because hey want to shape policy design and implementation in line with their views and values (Gains et al., 2008; Gains and John, 2010). Hence, in a scenario where input from citizens is at odds with that from political principals, one would expect bureaucrats to use their discretion and act upon what their values - personal and professional propel them to do.

Conflicts between what bureaucrats are asked to do, their professional values, what they believe is "good" for their clients and the policy demands made by their principals can stifle motivations to enact policies as proposed (Tummers et al., 2012). Following this logic, bureaucrat behaviour in response to conflicts between politician and citizen input will be a function of 
their desire to shape policy and the values they hold.

\section{Representative democracy and behavioural public ad- ministration theories}

The idea that bureaucrats could enact their functions in a way that will largely subconsciously - negatively affect certain citizen groups has long been formalised in theories of representative bureaucracy (Meier, 2018, see for a recent overview). At its core is the idea that demographic characteristics and identities attached to them - race, age and gender foremost - will bias bureaucrats to respond more to their own kind than to citizens who fall outside these categories. More recently, theories of behavioural public administration have suggested something more simplistic: bureaucrats react as intended if it were not for pesky behavioural biases that distort their response.

While representative bureaucracy theory is well researched, it might not capture all unconscious biases that are relevant for evaluations of participatory governance processes. Behavioural biases such as motivated reasoning could be at play. Motivated reasoning and biases that affect the evaluation of the quality of input provided by citizens require both - an understanding of systematic, culturally-defined biases and more simple, ad-hoc biases that occur during the processing of stimuli. For instance, the literature on motivated reasoning shows, voters (Redlawsk, 2002; Donovan et al., 2019; Már and Gastil, 2019), politicians (Walgrave et al., 2018) and bureaucrats 
(Baekgaard et al., 2019) all alike might provide sound explanations why they prefer certain policies over others, yet their evaluations are biased by other factors such as social identity and information frames.

However, (nascent) theories of behavioural public administration tend to neglect the role of power and institutional setting (Bertelli and Riccucci, 2020), which can affect the expression of bias. It is questionable to what extent ad-hoc responses to stimuli such as information frames will have larger effects than institutional facts such as politicians having greater direct power over the careers of bureaucrats than citizens.

Based on the expectations attached to public participation processes and the demands put on bureaucrats - objectivity and expertise markedly - it is expected that bureaucrats will rationalise their choices by paying particular attention to markers of legitimacy, relevance and adequacy of citizen input.

How information is framed will matter. The effect of information frames is one of the most widely studied biases in policy-relevant decision-making Kahneman and Tversky, 1984; Chong, Dennis and James N. Druckman, 2007; Arceneaux, 2012).

In the now famous framing study conducted by Kahneman and Tversky (1984), people's policy choice changed when the options were framed as losses rather than gains. Most political science literature on framing studies its effect on vote choices and public opinion (Lau and Schlesinger, 2005; Druckman and McDermott, 2008; Olsen, 2013, 2015). Few studies look at the effect of information frames on the decision-making of bureaucrats. After 
Herbert Simon pioneered the study of non-rational behaviour in the realm of politics, agency and firm behaviour (see Bendor (2003) for a commentary on Simon's work and influence on the field of political science), the field reverted back mostly to principal-agent models that were dominated by rational or quasi-rational actors. Exemptions are few but generally support the idea that bureaucrats are subject to framing effects just as much as other individuals. Banuri et al. (2018), illustrate this in a survey experiment with staff from the World Bank and DFID, the UK's department for international development. They find that ideologically and emotionally loaded words change how accurately bureaucrats evaluate evidence. Bureaucrats are more likely to accept or dismiss a scientific claim when it is ideologically loaded than when it is not. Belardinelli et al. (2018) replicate framing effects with a sample of Italian bureaucrats. The same stimuli were used on a non-bureaucrat sample by Olsen (2015), with similar results. The bureaucrats are asked to evaluate the performance of contractors based on satisfaction ratings provided by citizens. When the same ratings are presented with a negative frame, bureaucrats are more likely to provide lower performance scores than when a positive frame is used. Literature on street-level, compared to office- and more senior bureaucracy, has seen a greater proliferation of work on framing in particular and behavioural biases affecting bureaucrat decision making more generally: $!^{3}$

\footnotetext{
${ }^{3}$ Literature on street-level bureaucrats tends to portray them as actors with power, motivation and a mission, but riddled with biases and emotion - a view very different to the homo economicus dominant in principal-agent models.
} 
This literature provides many real life case studies of the behaviour and bias of bureaucrats.

Street-level bureaucrats use mental shortcuts such as stereotypes Lipsky, 1983) and signals (Raaphorst and Van de Walle, 2017), to define and sort citizens they interact with into different policy-relevant groups. Andersen and Jakobsen (2016) test the causal relationship between frames - professional values, citizen-centred policy and empirical research - and the decisions of bureaucrats in an experiment with state-employed teachers (street-level bureaucrats) in the US and Denmark. Across three experiments, they find that using frames that emphasise professional norms significantly change the policy choices of bureaucrats. However, the case that Andersen and Jakobsen (2016) study is a peculiar one: they test whether making a policy appear as beneficial to the clients (students) of bureaucrats (teachers) makes the bureaucrats (teachers) more likely to support adoption of such a policy. They do not acknowledge the professionalised context in which teachers might differ from other types of bureaucrats in how they respond to their constituents. It thus remains unclear how such effects replicate in different types of bureaucrat populations.

\section{Hypotheses}

Bureaucrats might always try to maximise their discretion and prioritise their own knowledge over that of politicians and citizens. However, to what extent they feel the license to do so is expected to vary with the presence of 
conflict. If there is conflict, bureaucrats should feel more pressured to take a side to facilitate choosing one option over the other. Principal-agent theories predict that bureaucrats will yield to those principals with more and more direct power over their futures. Hence:

Hypothesis 1 When feedback is conflicting, bureaucrats will yield more to the demands of politicians than citizens.

Based on existing research, it is anticipated that information frames will affect the decisions of bureaucrats (Chong, Dennis and James N. Druckman, 2007; Druckman and McDermott, 2008). As discussed in earlier sections, how bureaucrats will evaluate certain information frames might correlate strongly with their professional identities and the norms they have adopted through professional socialisation. There are however two types of information frames which are widely prevalent across professions and highly relevant for the ability of public participation processes to influence policy choices:

Information from public participation processes is either summarised in a qualitative manner or relies on larger scale data collection efforts that aim for statistical representativeness. While the former claims legitimacy through claims about selecting the relevant and righteous group of stakeholders, the latter does so through strength in numbers. Depending on their ontological outlook, bureaucrats might be more convinced by either a qualitative or a quantitative frame. On top of ontological considerations, qualitative evidence provides for greater use of emotional cues. An ample 
body of literature has shown that information frames containing emotional cues are more persuasive than evidence presented without such cues (Lau and Schlesinger, 2005; Druckman and McDermott, 2008; Brader et al., 2008; Arceneaux, 2012; Nuñez et al., 2015). Emotive language should make citizens' demands more persuasive and thus increase responsiveness towards citizens in general. Moreover, information that is high in affect can elicit more risk-hungry behaviour than the same information that is low in affect (Rottenstreich and Hsee, 2001; Petrova et al., 2014). Qualitative information might therefore render bureaucrats more responsive to citizens' demands, especially when risk matters - in a conflict scenario, when they have to speak up against their political prinicpal. A hierarchy of effects can be expected:

Hypothesis $\mathbf{2}$ When the information is presented in a qualitative way, using emotional words, bureaucrats will be more responsive to citizens than if it is described in a quantitative way, lacking emotional words.

If input is emotional-qualitative, bureaucrats will discount risks and be more willing to respond to citizen input.

$$
Y_{\text {NoConflict }}^{\text {Quali }}>Y_{\text {NoConflict }}^{\text {Quant }}>Y_{\text {Conflict }}^{\text {Quali }}>Y_{\text {Conflict }}^{\text {Quant }}
$$

While information frames are expected to shift responses, considerations of risk and power entailed in facing conflicting input from political and citizen principals is expected to have greater influence on bureaucrat behaviour. 
Hypothesis 3 Framing effects will be smaller than the effects of conflict, so that bureaucrats are always less responsive in conflict scenarios than when there is no conflict.

\section{Research design}

The study was pre-registered at EGAP, 4 The design and analysis described below follows this pre-registered plan unless stated otherwise. The survey experiment has a $2 \times 2$ factorial design. Each participant receives two scenarios: one conflict and one non-conflict scenario. Half of the respondents receive information with an informational frame and half with a quantitative frame.

The emotional-qualitative information frame is modelled on qualitative methods typically used to aggregate the results of public participation processes, while the quantitative frame is akin to results from email or online surveys, which are another popular mechanism used for inter-electoral public participation processes.

The frames tested in this experiment are thus what Druckman called equivalency or valence frames as opposed to value or issue frames (Druckman, 2001). More conscientious or risk-averse bureaucrats might react very differently to conflict compared to more daring, less conscientious ones. The design allows to average out such individual differences as each respondent acts as their own control when comparing reponses to conflict and non-conflict sce-

\footnotetext{
${ }^{4}$ EGAP registration number: 20171013AA. The pre-analysis plan is available for download at http://egap.org/registration/2884.
} 
narios.

Framing effects, to the contrary, have been replicated across many settings and population groups (Druckman, 2001). It is less likely that responses to information frames are heterogeneous. Apart from the experimentally manipulated factors, conflict and information frame, one would also expect the topic and the source of information to influence bureaucrats' decisions (Hartman and Weber, 2009).

The topic is chosen in such a manner that it is broadly relevant for any bureaucrat, regardless of their area of work (more detail on this in the section on interventions). Ideally, content of input is kept constant across the conflict and non-conflict situations to isolate effects. However, showing bureaucrats the same scenario twice, once with a conflict and once without, is obtrusively artificial. Therefore, two different scenarios are used but the matching and order of the scenarios is radnomly assigned. Thereby, the effect of conflict remains uncorrelated with the type of scenario. What is more, since each respondent receives both scenarios, individual differences in reaction propsensities based on topic choice will average out.

One other important factor to consider is that disagreement is directional: $\mathrm{X}$ disagrees with $\mathrm{Y}$. There is a judge $(\mathrm{J})$ and an opinion-provider $(\mathrm{O})$. Holding the scenario and status of the demands constant (conflict or no conflict), responsiveness might be a function mainly of the norms that bureaucrats hold $(\mathrm{N})$, interaction between source - politician $(\mathrm{P})$ or citizen $(\mathrm{C})$ - and their role in the communication - judge $(\mathrm{J})$ or opinion provider $(\mathrm{O})$ : 
Table 1: OLS regression: treatment effect on client-value conflict

\begin{tabular}{ll|ll}
\hline \multicolumn{4}{c}{ Experimental conditions } \\
\hline & \multicolumn{1}{c}{ Conflict } & Scenario \\
\hline \multirow{2}{*}{ Information frame } & \multicolumn{2}{c}{ Emotional/qualitative frame } \\
& Quantitative frame & Emotional - Conflict & Emotional - No conflict \\
\cline { 2 - 4 } & Qant - Conflict & Quant - No conflict \\
\hline
\end{tabular}

$$
\text { Responsiveness } \approx f(\operatorname{Norm}[N], \text { Source }[P, C], \text { Role }[J, O])
$$

For this reason, whether the politician or the citizen is the judge (the disagreeing party) is also randomised. It is not feasible to analyse the effect of these randomised factors on behaviour since the sample size required to measure them with adequate power exceeds the scope of this study. However, the balance of covariates for these factors is provided. Further, measures for the responsiveness to suggestions made by politicians and citizens are presented separately (see section for more details). This further allows to parcel out the effect by information source.

Despite the existence and significant impact of framing effects having been empirically verified across many contexts and employing a variation of research designs, it is important to note that in real life situations the effect size of frames will likely be smaller than in laboratory and survey experiments. Druckman (2004) finds evidence in support of this in a randomised control experiment (albeit confined to the laboratory). 


\section{Experiment materials}

Before the experiment, a pilot was conducted with 120 participants who work in the public sector, recruited via MTurk. Twelve vignettes were tested to pick those that were well understood and showed clear response patterns. More information on the design and results of the pilot are available in the Appendix. Bureaucrats likely evaluate the vignettes with reference to their own area of work and experiences. The vignettes tested were relevant for all types of bureaucrats; communication strategies and policies regarding responses to enquiries made by citizens. While not all bureaucrats would be tasked personally with the implementation of such policies, they will exist

in one form or another for their agency, service or department. Qualitative responses to two open-ended questions at the end of the survey suggest that participants were able to make this connection and translate the scenario to their particular work context. The results of the open-ended questions are discussed in more detail in the results section and in the Appendix.

Of the twelve tested vignettes, two performed well. These were adapted them further to provide the best fit to test them on both US and UK bureaucrats. Further, the language of the survey response options for the area of work and terms for political principles was adapted for each of the contexts. The equivalence and recognisability of terms was discussed and adjusted with the help of 15 former UK and US bureaucrats. A list of these terms is available in the Appendix After having consented to take part, bureau- 
Table 2: Overview of treatment messages

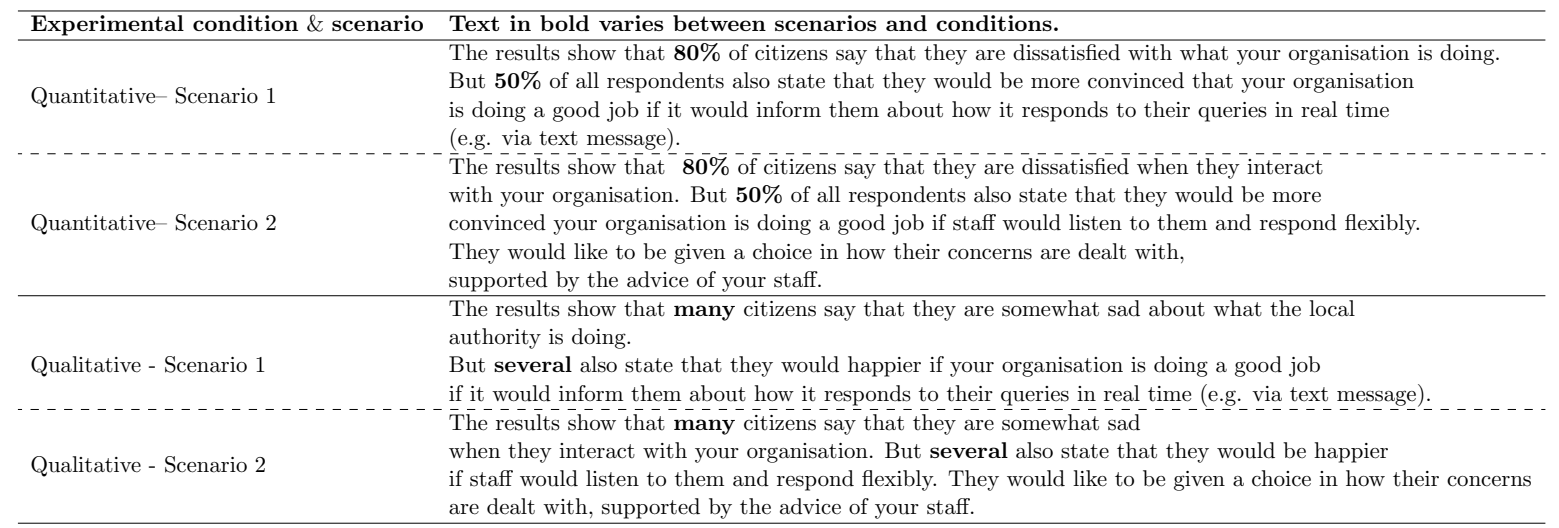

crats each received two vignettes. The order of presentation was randomised.

One vignette portrayed their political principal and the citizen group to be in agreement. The other vignette depicted them to be in conflict. In the conflict scenarios, who disagrees with whom was randomised.

Information included in the vignettes was purposely ambiguous and complex to mimic the type of feedback bureaucrats routinely receive as part of participation initiatives. The choice of emotional words was based on previous research and results from the pilot. Studies on emotional words have shown that there are basic emotions that are easily distinguishable for people of all ages and most cognitive levels - most commonly reduced to four: happy, sad, angry and scared (Tracy and Randles, 2011). Pilot data for this project reflected these claims. Responses differed more clearly between frames when basic emotional words than more complex ones were used. 
Table 3: Variation in treatment text

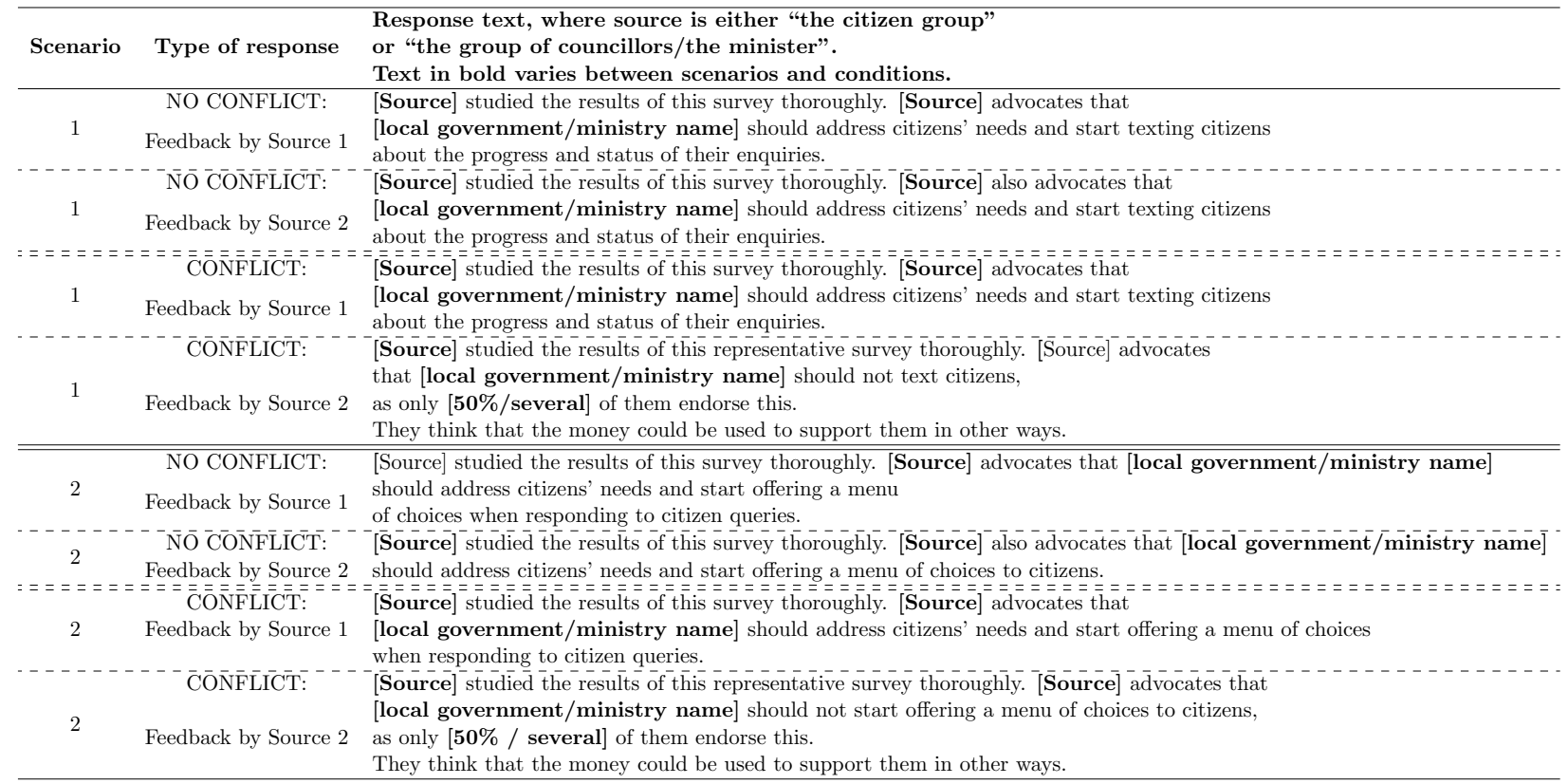

\section{Outcomes and covariates}

The main outcome is willingness to respond. It is a proxy of how motivated and persistent a bureaucrat will be in their pursuit of adopting or preventing suggested policy changes. Bureaucrats are asked to rank their willingness on a seven-point scale. The scale was validated by Tummers et al. (2012).

$$
\left.W_{i, s} \in[1,7]\right]
$$

To assess relative responsiveness to citizen demands compared to politician demands, a ratio of willingness to respond to citizens' demands to the willingness to respond to politicians' demands is taken. 


$$
Y_{i, s}=\frac{W_{i, s}^{\text {citizen }}}{W_{i, s}^{\text {politician }}}
$$

where i stands for the observation of participant $i$

$$
\text { and } \mathrm{s} \text { denotes the scenario (one or two) }
$$

If the ratio is 1 , then willingness is equal. If the ratio is less than 1 , then willingness is greater for responding to the citizen. The chosen plan of action is the secondary outcome. While bureaucrats might be sympathetic towards citizen concerns, when they are confronted with a choice and the consequences that such a choice will entail - e.g. it might negatively reflect on their career -, they will support whatever their political principal supports. In the conflict scenario, bureaucrats are asked whether they would support what the citizens or what their political principal proposed, or whether they would choose to openly disagree with both. In scenarios without conflict, bureaucrats are asked to choose whether they will adapt the suggestions made by the citizens and the political principal or whether they choose to object to them. Bureaucrats can thus choose one of three options in the conflict scenario and one of two in the non-conflict scenario.

$$
P_{i}^{\text {Conflict }} \in[0,1,2]
$$




$$
P_{i}^{\text {Noconflict }} \in[0,1]
$$

This introduces asymmetry but approximates real life scenarios more closely. The presence of conflict will change the number of parties a bureaucrat can align themselves with. To compare responses across scenarios, responses are converted into z-scores.

Personal characteristics are expected to affect responses. For instance, women tend to be more positive in their responses in surveys (?). Those who work in pro-social front-line services such as teachers or social workers will likely be more responsive than bureaucrats whose clients consist of less vulnerable populations. Since they face different risks, more senior staff and those on higher salaries might also react somewhat differently. Those with higher education attainments are more likely to be comfortable with using statistics and might therefore respond somewhat more consistently to the numeric framing than those with lower numeracy. The area of work, seniority and gender, education and income of bureaucrats are accounted for by including them as pre-treatment covariates in the estimation of the average treatment effect. Professional values and how suggestions made by citizens and politicians reflect on them should further affect responses. Scales on client-policy and client-value conflicts developed by Tummers et al. (2012) are therefore included. To manage trade-offs between the number of items included and the robustness of instruments, the three elements of the scale are chosen, which had the highest factor loadings as indicated by data from 
the pilot.

1. Working with the policy clashes with the wishes of many clients

2. My clients experience the policy as a breach of their privacy

3. Working with the policy conflicts with my values and norms as a professional

Pilot data indicated that the adapted items had high inter-item correlations ( 0.84 between the two professional-value conflict measures, and 0.65 and 0.66 for the professional-value conflict measures and the professional-client measures see section ). At the very end of the survey, there were two free text fields, which asked bureaucrats to comment on (i) what they perceive to be barriers to more effective citizen engagement and (ii) to explain why they chose as they did in the experiment. All survey questions are included in the Appendix. 


\section{Estimation of treatment effects}

An OLS regression is used to estimate the average treatment effect, with the following specification.

$$
Y_{i, s}=\alpha+\beta_{1} T_{i, s}+\beta_{2} S_{i}+\beta_{3} T_{i, s} \times S_{i}+\gamma_{1} X_{i, s}+\epsilon_{i s}
$$

$Y_{i, s}$ is the outcome of interest, observed for participant $\mathrm{i}$ in scenario $\mathrm{s}$

$T_{i, s}$ is a binary variable which is zero when participant $\mathrm{i}$

was randomised into the numeric condition and one if they were randomised into the emotional condition

$S_{i}$ is a binary variable for which zero is the conflict scenario

and one the no conflict scenario observed by participant i

$X_{i, s}$ is a vector of covariates as specified in the section above

Note that there is only one observation of demographic covariates and for the value of citizen feedback for participant i but there are two observations for perceived conflict, one for each scenario.

$\beta_{1}, \beta_{2}, \beta_{3}$ are the coefficients of interest.

$\epsilon_{i, s}$ is an error term clustered for participant $\mathrm{i}$ in scenario $\mathrm{s}$ 


\section{Recruitment and randomisation}

The bulk of the sample was recruited using Prolific.ac (Prolific hereafter). Prolific is a professional panel provider with roots in academia. According to recent tests, Prolific provides good quality of responses. Peer et al. (2017) tested the reliability indices of several scales across Prolific, Amazon's Mechanical Turk (MTurk) - the most commonly used online recruitment platform in academia to date -, and a handful of other platforms. The results from Prolific were statistically indistinguishable from those obtained from MTurk, apart from scores on attention and those of a quality test. On this test, participants recruited via Prolific performed better than those recruited on MTurk. Significantly more respondents passed the attention test on Prolific than on MTurk. Apart from these encouraging findings, for this study Prolific was a more suitable platform than MTurk and alternative recruitment platforms. Predictiv contrary to others offered a large pool of bureaucrats based in the UK as well as the US. Further, Prolific makes it more difficult to prevaricate on screening characteristics than MTurk (Palan and Schitter, 2018), providing further confidence that participants truly were who they presented to be. Similar to other platforms, participant IDs on Prolific are unique and can be tracked across studies. Researchers can screen participants via their IDs; for instance, only allowing previous participants into a new study or excluding them from further studies.

While online panel providers offer many advantages compared to offline 
recruitment, such as reduced experimenter demands, lower cost and more demographically diverse panels, online panels struggle to attract higher income individuals. Consequently, they are less likely to attract bureaucrats who have more senior roles - i.e. those bureaucrats who have managerial responsibilities and are involved in organisational strategy and agenda-setting. To reach such bureaucrats, the study was advertised at events and meetings targeted at senior bureaucrats. Eevents ranged from small-scale meetings with experts to large scale "civil service conferences' where hundreds of senior bureaucrats congregated. In the US, the link was distributed to the survey with an explanation about its purpose via the Slack channel of the US What Works Cities network Slack is a collaboration tool with a chat function at its core. Many government and quasi-governmental organisations in the US and UK now use it to collaborate across teams, departments and agencies..

In the UK, senior bureaucrats at the UK's Civil Service Live conference were asked to complete the experiment in their waiting time before a talk started. Civil Service Live is the UK's largest conference for public servants and takes place annually. Three talks, each on a different day, with a different speaker and spread across two venues, were used for recruitment purposes. The survey link was also provided to attendees at a meeting of the senior bureaucrats running a large local government in the UK and a cross-authority government meeting group. Through these offline efforts, a total of 93 senior bureaucrats were recruited. On Prolific the survey was advertised to panel members who had indicated on their profiles that they had managerial re- 
sponsibilities. At the end of the survey, they were asked to specify their job level: officer, junior management, senior management and executive.

Bureaucrats recruited offline make up $40 \%$ of the sample of senior and executive bureaucrats, but only $12 \%$ of the entire sample. While one might suspect that they will act differently to bureaucrats recruited via the online platforms. As the results demonstrate, that this is not the case.

\section{Divergence from the pre-analysis plan}

When the pre-analysis plan was written, it was unclear that policy value and policy-client conflict could be measured only as a post-treatment variable. If it were included in the regression as pre-specified it would likely bias estimates (Nyhan and Reifler, 2010). Instead these two variables are analysed as additional, exploratory outcomes and mark analyses as such.

\section{Results}

\section{Description of data}

There is no significant association between assignment to treatment and at-

trition (Table 4). There is no attrition check for bureaucrats recruited at the local government executive meeting because all 15 attendees completed the experiment.

Blocked (stratified) randomisation was infeasible due to logistical con- 
Table 4: Attrition checks

\begin{tabular}{lllll}
\hline Sub-sample & Variable & Coef. & SE & $\begin{array}{l}\text { p-value } \\
\text { (unadj.) }\end{array}$ \\
\hline Prolific USA & Numeric/emotional & -.025 & .026 & .34 \\
Prolific USA & Conflict first/second & -.016 & .025 & .51 \\
Prolific USA & Type of no-conflict scenario & .036 & .025 & .15 \\
Prolific USA & Type of conflict scenario & -.036 & .025 & .15 \\
What Works USA & Numeric/emotional & -.212 & .336 & .54 \\
What Works USA & Conflict first/second & -.292 & .278 & .32 \\
What Works USA & Type of no-conflict scenario & .156 & .297 & .61 \\
What Works USA & Type of conflict scenario & -.156 & .297 & .61 \\
CSL UK & Numeric/emotional & -.094 & .064 & .14 \\
CSL UK & Conflict first/second & .113 & .065 & .08 \\
CSL UK & Type of no-conflict scenario & .013 & .065 & .84 \\
CSL UK & Type of conflict scenario & -.013 & .065 & .84 \\
Cross-auth network & Numeric/emotional & .021 & .151 & .89 \\
Cross-auth network & Conflict first/second & .079 & .153 & .61 \\
Cross-auth network & Type of no-conflict scenario & .108 & .146 & .46 \\
Cross-auth network & Type of conflict scenario & -.108 & .146 & .46 \\
Prolific UK & Numeric/emotional & .013 & .02 & .50 \\
Prolific UK & Conflict first/second & .003 & .02 & .88 \\
Prolific UK & Type of no-conflict scenario & -.01 & .02 & .62 \\
Prolific UK & Type of conflict scenario & .01 & .02 & .62 \\
\hline
\end{tabular}

straints. 5

However, as Table 5 illustrates, the sample is balanced on all observable demographic characteristics. There is an imbalance in terms of recruitment source. Bureaucrats recruited offline were assigned at a higher rate to receive the conflict scenario first $(66 \%$ vs $50 \%, \mathrm{p}<0.01)$. An additional robustness check is provided, which compares responses from bureaucrats recruited offline with those recruited online.

\footnotetext{
${ }^{5}$ Due to the rarity of the target sample, senior bureaucrats, the recruitment period spanned several months. It was impossible to know which type of bureaucrat would decide to participate at which point in the recruitment period. Quotas could therefore not be set ex-ante. A rolling blocked randomisation would have required continuous checks against the existing databases. This was not possible with the technical set-up available.
} 
Table 5: Balance checks (post-treatment)

\begin{tabular}{|c|c|c|c|}
\hline Covar. & Coef. & SE & $\begin{array}{l}\text { p-value } \\
\text { (unadj.) }\end{array}$ \\
\hline Gender & .007 & .038 & .86 \\
\hline Age cat. & .002 & .081 & .98 \\
\hline Gov. sector & .05 & .062 & .42 \\
\hline Seniority level & -.02 & .06 & .74 \\
\hline Order of within-subj. treatment & -.053 & .037 & .15 \\
\hline Scenario used - Conflict & .02 & .037 & .59 \\
\hline Scenario used - No conflict & -.022 & .051 & .67 \\
\hline Country & -.006 & .037 & .88 \\
\hline
\end{tabular}

As pre-specified for the other balance checks, analyses use OLS regressions with robust standard errors and covariate adjustment to regress offline recruitment (binary) on the key outcomes. Bureaucrats who were recruited offline do not differ in terms of willingness from those recruited online $(\mathrm{p}=0.31)$, nor when they make a choice in the conflict scenario $(\mathrm{p}=0.90)$. They are about 9 percentage points more likely to accept a suggestion rather than suggest something else in the no conflict scenario, but this is only significant at $\mathrm{p}<0.1$. ${ }^{6}$ An additional robustness check for every analysis is provided, in which a dummy variable is added for recruitment tactic. None of the conclusions change following the addition of this dummy.

In terms of demographic characteristics, the final sample comprised of slightly more female than male bureaucrats (60\% vs $40 \%$, Figure11). Notably, many front-line public services - schools, social work, health care and streetlevel administrative services - are female dominated. Given the composition of the sample, the gender bias is thus not surprising but more a reflection of

\footnotetext{
${ }^{6}$ This is the p-value before adjusting for multiple comparisons.
} 
the equivalent bias existent in the public sector workforce.

Regarding age, the sample had a typical range for professions that require university/college education, but almost $80 \%$ of the sample were below the age of 45 (Figure 2). It is likely that this is due to Prolific being an online platform, which attracts younger people at a higher rate than older individuals. In terms of government sector, the distribution is very similar to that of the UK and US public workforce: most people are employed in front-line services or in local government (Figure 3). The same applies for the seniority of participating bureaucrats. There are more people at lower levels of management than higher ones (Figure 4). In terms of work location, $51 \%$ of participants were recruited from the UK and $49 \%$ from the US (Figure 5). 


\section{Willingness to respond}

The primary outcome was the stated willingness of a bureaucrat to respond to citizen demands relative to politician demands. If the value is above one, the bureaucrat is more willing to respond to the citizen compared to the politician.

Looking at the distribution of answers by conflict, it is already evident that there is a greater spread of responses in the conflict scenario than under "no conflict", where answers cluster more around one (Figure 7). Under agreement bureaucrats are similarly willing to respond to citizens and politicians but under conflict they are more responsive to citizens than politicians (Table 6). Their willingness increases by 0.85 standard deviations - a large effect. Under conflict bureaucrats become less willing to respond to both citizens and politicians (Figure 6, Figure 8). However, they reduce responsiveness at a higher rate for politicians, making them relatively more open to citizen suggestions. Information frames had no significant effect (Table 6). Bureaucrats rate their willingness to respond to citizens (Figure 9, Figure 10) and politicians (Figure 11, Figure12) similarly, regardless of whether the information used emotional-qualitative words or a purely quantitative frame. Differences are not statistically significant. 
Table 6: Primary analysis: OLS regression estimating treatment effects on willingness in response to demands

\begin{tabular}{|c|c|c|}
\hline & $\begin{array}{c}(1) \\
\text { Willingness } \\
\text { b/se }\end{array}$ & $\begin{array}{c}(2) \\
\text { Willingness - with demogs added } \\
\mathrm{b} / \mathrm{se}\end{array}$ \\
\hline Emotional & $\begin{array}{c}0.025 \\
(0.019)\end{array}$ & $\begin{array}{c}0.024 \\
(0.020)\end{array}$ \\
\hline Conflict & $\begin{array}{c}0.245^{* *} \\
(0.050)\end{array}$ & $\begin{array}{c}0.245^{* *} \\
(0.050)\end{array}$ \\
\hline Emotional $\times$ Conflict & $\begin{array}{c}0.085 \\
(0.077)\end{array}$ & $\begin{array}{c}0.085 \\
(0.077)\end{array}$ \\
\hline Constant & $\begin{array}{c}1.015^{* *} \\
(0.013)\end{array}$ & $\begin{array}{c}1.020^{* *} \\
(0.065)\end{array}$ \\
\hline$R^{2}$ & 0.04 & 0.05 \\
\hline Covariates added & No & Yes \\
\hline Observations & 1440 & 1440 \\
\hline
\end{tabular}




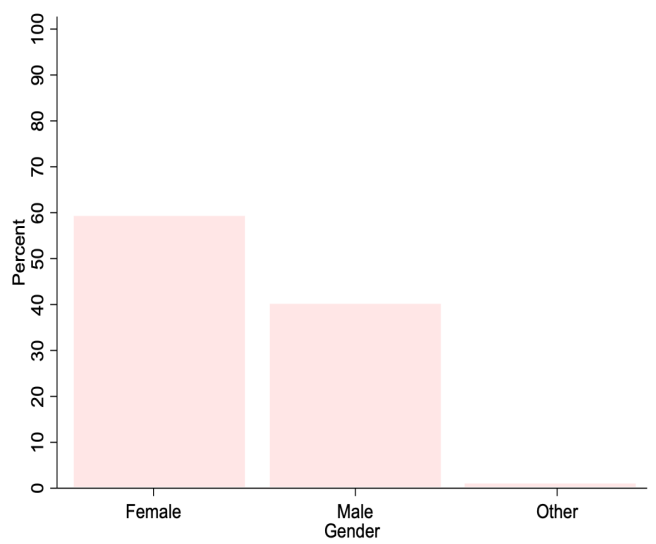

Figure 1: Gender composition of sample

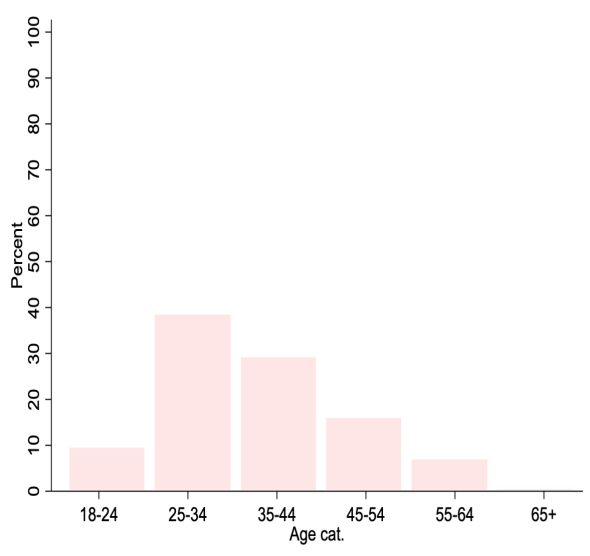

Figure 2: Age composition of sample 


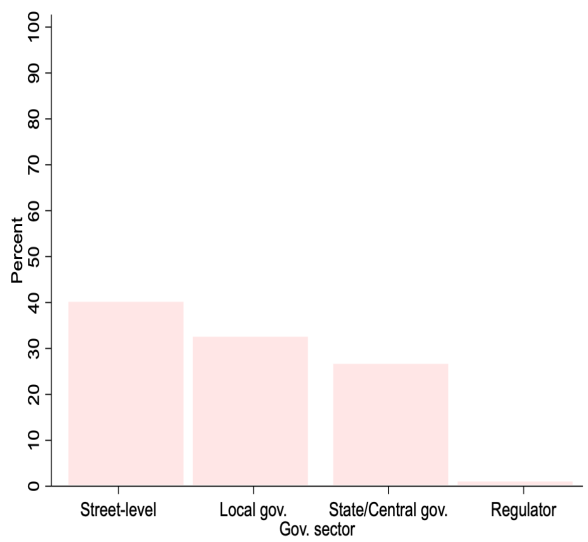

Figure 3: Government sector of employment of sample

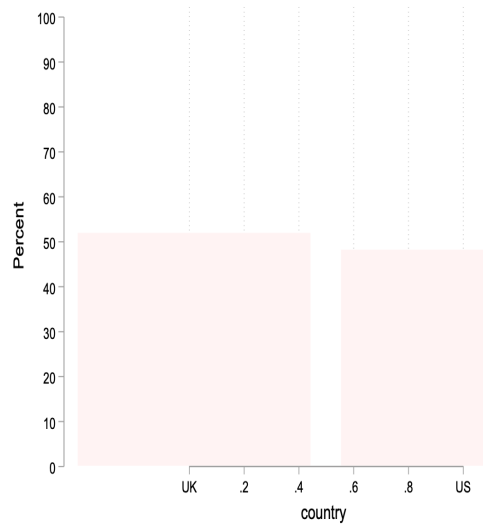

Figure 5: Country of work of sample

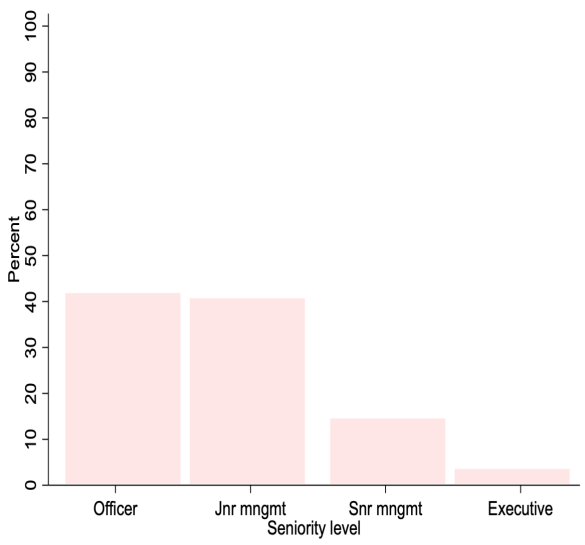

Figure 4: Job level of sample 


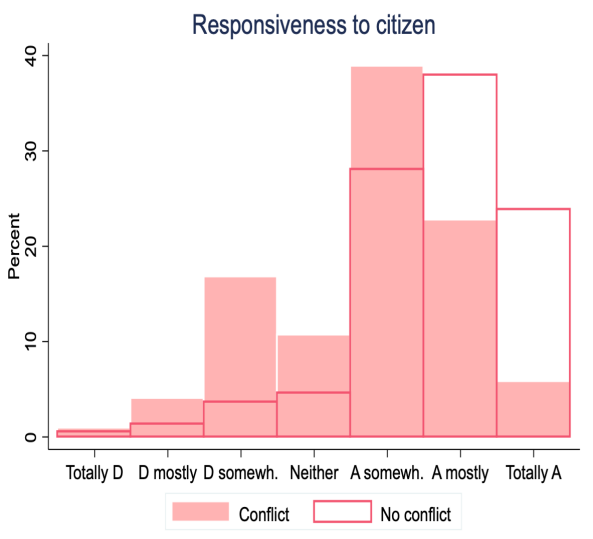

Figure 6: Willingness to follow citizen suggestions under no conflict

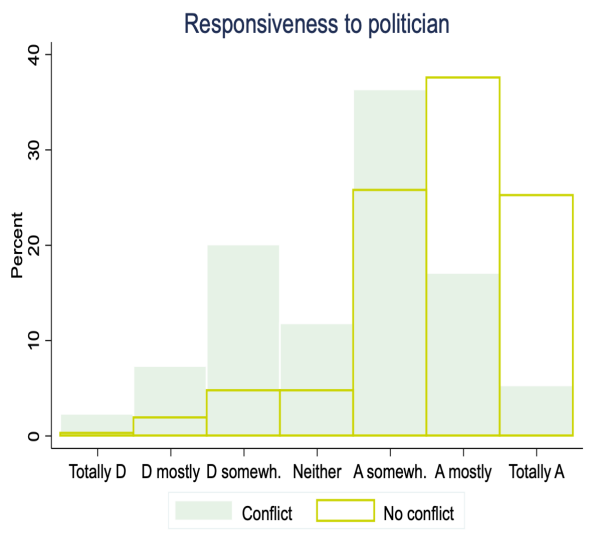

Figure 8: Willingness to follow citizen suggestions under no conflict

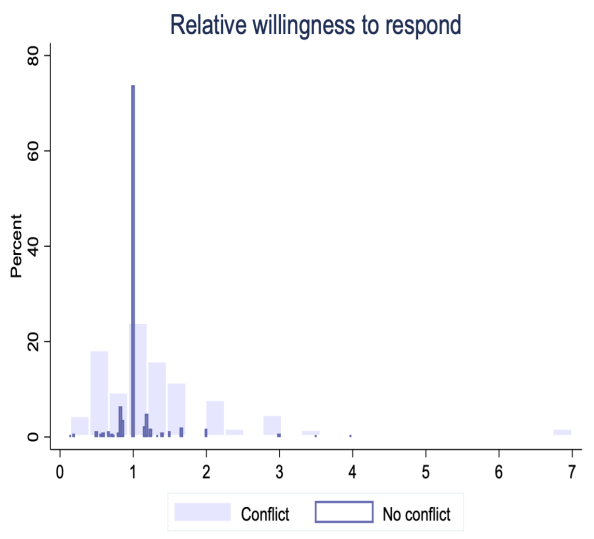

Figure 7: Willingness to follow citizen suggestions under no conflict 
Table 7: OLS regression estimating treatment effects on willingness in response to citizen and politician demands

\begin{tabular}{|c|c|c|c|c|c|c|}
\hline & $\begin{array}{c}\text { (1) } \\
\text { Willingness - Citizen } \\
\text { b/se }\end{array}$ & $\begin{array}{c}(2) \\
\text { Willingness - Citizen } \\
\text { b/se }\end{array}$ & $\begin{array}{c}\text { (3) } \\
\text { Willingness - Citizen } \\
\text { b/se }\end{array}$ & $\begin{array}{c}(4) \\
\text { Willingness - Politician } \\
\text { b/se }\end{array}$ & $\begin{array}{c}(5) \\
\text { Willingness - Politician } \\
\text { b/se }\end{array}$ & $\begin{array}{c}(6) \\
\text { Willingness - Politician } \\
\text { b/se }\end{array}$ \\
\hline \multirow{2}{*}{ Emotional } & 0.092 & 0.093 & 0.092 & 0.004 & 0.001 & -0.002 \\
\hline & $(0.085)$ & $(0.086)$ & $(0.086)$ & $(0.088)$ & $(0.088)$ & $(0.088)$ \\
\hline \multirow[t]{2}{*}{ Conflict } & $-0.883^{* *}$ & $-0.883^{* *}$ & $-0.883^{* *}$ & $-1.153^{* *}$ & $-1.153^{* *}$ & $-1.153^{* *}$ \\
\hline & $(0.085)$ & $(0.085)$ & $(0.085)$ & $(0.097)$ & $(0.098)$ & $(0.098)$ \\
\hline \multirow[t]{2}{*}{ Emotional $\times$ Conflict } & -0.093 & -0.093 & -0.093 & -0.122 & -0.122 & -0.122 \\
\hline & $(0.116)$ & $(0.117)$ & $(0.117)$ & $(0.136)$ & $(0.137)$ & $(0.137)$ \\
\hline \multirow[t]{2}{*}{ offline $=1$} & & & 0.074 & & & 0.172 \\
\hline & & & $(0.138)$ & & & $(0.122)$ \\
\hline \multirow[t]{2}{*}{ Constant } & $5.626^{* *}$ & $5.836^{* *}$ & $5.831^{* *}$ & $5.665^{* *}$ & $5.557^{* *}$ & $5.547^{* *}$ \\
\hline & $(0.063)$ & $(0.173)$ & $(0.172)$ & $(0.065)$ & $(0.146)$ & $(0.145)$ \\
\hline Covariates added & No & Yes & Yes & No & Yes & Yes \\
\hline$R^{2}$ & 0.13 & 0.14 & 0.14 & 0.18 & 0.21 & 0.21 \\
\hline Observations & 1440 & 1440 & 1440 & 1440 & 1440 & 1440 \\
\hline
\end{tabular}




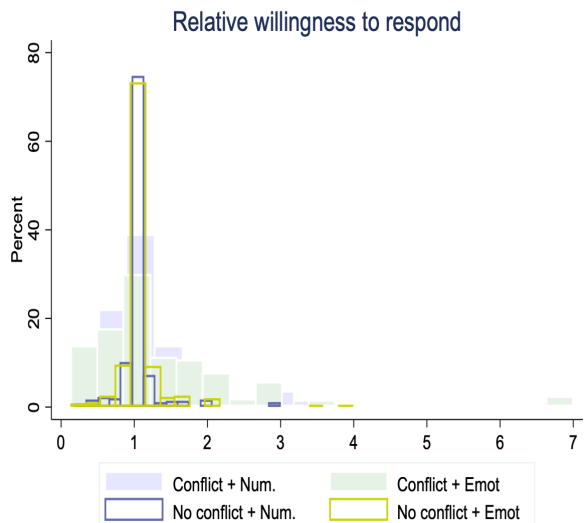

Figure 9: Willingness to follow citizen suggestions under no conflict and under conflict

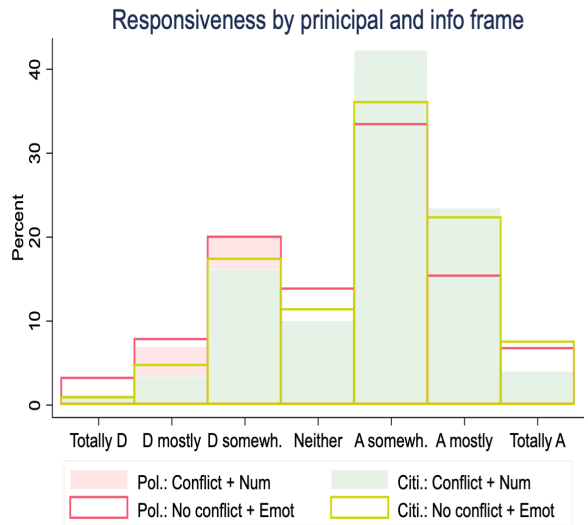

Figure 10: Willingness to follow citizen / politican suggestions, by information frame

\section{Choice of action}

The secondary outcome was choice of action. Bureaucrats tend to reject demands regardless of framing and conflict (Table 8). Notably, rejection rates are high (Figure 13, Figure 14). In the no conflict scenario $90 \%$ of bureaucrats reject the suggestion made by the politician and citizen, albeit the two parties agree. This is considerably lower in the conflict scenario, where $44 \%$ of bureaucrats reject both suggestions. However, bureaucrats accept politician and citizen suggestions at a near equal rate (27\% and $29 \%$ ).

The information frames have no significant effect on responses (Table 8), but a trend towards being more accepting of citizen suggestions under the emotional-qualitative frame is observable (Figure 15, Table 8). 


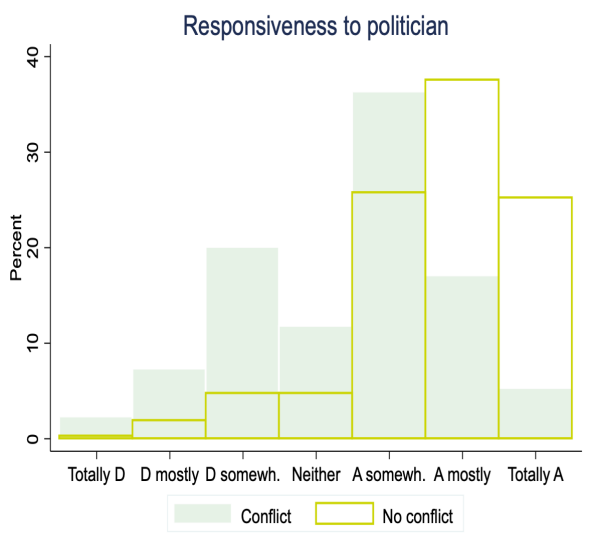

Figure 11: Willingness to follow politician suggestions

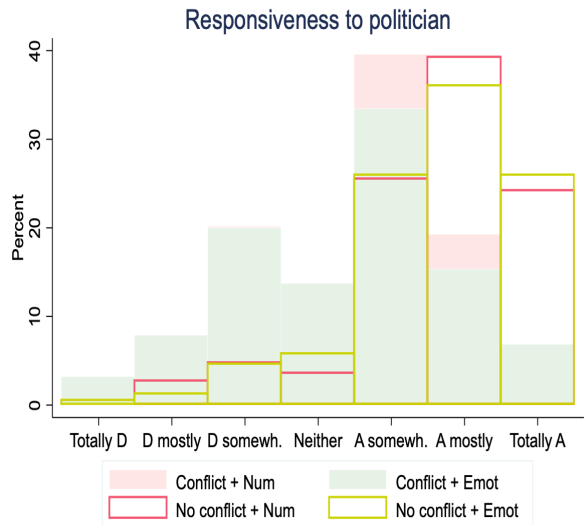

Figure 12: Willingness to follow politician suggestions, emotional/qualitative frame

\section{Testing potential mechanisms}

There might be different underlying reasons as to why conflict elicits the observed response. As hypothesised, shifts could be driven by the perceived risk of sanction and the differences between sanctions expected from politicians and citizens. Social identity and role concepts might be at play. Or the presence of conflict might alter how bureaucrats evaluate the legitimacy, relevance and adequacy of provided input.

Street-level bureaucrats are expected to be more responsive to citizens because of their proximity to them and the client orientation that many of these professions promote (e.g. teachers or public library staff). Since street-level bureaucrats dominate the sample in terms of numbers, it is assessed whether they drive the shift towards responsiveness to citizens (Figure 
Table 8: Secondary analysis: OLS regression to estimate the effect of treatment on chosen plan of action

\begin{tabular}{lcc}
\hline & $(1)$ & $(2)$ \\
& Choice \\
$\mathrm{b} / \mathrm{se}$ & Choice $-\begin{array}{c}\text { with demogs added } \\
\mathrm{b} / \mathrm{se}\end{array}$ \\
\hline Emotional & 0.061 & 0.063 \\
& $(0.074)$ & $(0.075)$ \\
Conflict & 0.046 & 0.046 \\
& $(0.073)$ & $(0.073)$ \\
Emotional $\times$ Conflict & -0.085 & -0.085 \\
& $(0.101)$ & $(0.102)$ \\
Constant & -0.033 & -0.181 \\
& $(0.052)$ & $(0.123)$ \\
\hline$R^{2}$ & 0.00 & 0.01 \\
Covariates added & $\mathrm{No}$ & Yes \\
Observations & 1440 & 1440 \\
\hline$+\mathrm{p}<0.1,{ }^{*} \mathrm{p}<0.05,{ }^{* *} \mathrm{p}<0.01$ &
\end{tabular}

16. Figure 17), using a non-parametric test (a Chi-squared for choice and a Wilcoxon-Mann-Whitney test for willingness).

When there is no conflict, street-level and centrally employed bureaucrats do not differ $(\mathrm{X} 2(1)=0.01, \mathrm{p}=0.92)$. Under conflict however street-level bureaucrats accept citizen suggestions at a lower rate than centrally employed bureaucrats $(\mathrm{X} 2(1)=11.76, \mathrm{p}=0.003)$. In terms of stated willingness to respond, street-level bureaucrats are consistently less willing to respond to citizen suggestions than more centrally employed bureaucrats, both when there is no conflict ( $\mathrm{z}=3.28, \mathrm{p}=0.001)$ and when there is conflict $(\mathrm{z}=2.75$, $\mathrm{p}=0.006)$.

Next, the effect of conflicting input on perceived client-value and professionalvalue conflict is explored. If client orientations are underlying a shift towards responsiveness to citizens, perceived client-value conflict too would increase. If socialisation and professional identities are at play, perceptions 
of professional-value conflict should increase. Indeed, disagreement between politician and citizen demands makes bureaucrats experience significantly more client-value and professional-value conflict (Table 9). This holds up even after adjusting the p-value for multiple comparisons using the very conservative Bonferoni correction. The unadjusted p-value is 0.05 . In each of the eight regressions, three comparisons are made, which sums to a total of 24 comparisons. Following the Bonferroni formula, the adjusted p-value is 0.002 .

Findings on the effects of the informational frames are more mixed and only significant at $\mathrm{p}<0.1$, without adjusting for multiple comparisons. Directionally, values however shift as expected: Perceived conflict in response to citizen demands is attenuated by the informational frame, especially when citizens and politicians disagree ( $\mathrm{p}<0.1$ for each of the tested interactions). On the contrary, perceived conflict in response to politician demands is not influenced by the information frame ( $\mathrm{p}>0.6$ for each of the comparisons).

To better understand how bureaucrats evaluate their choices, we next turn to results of the open-text responses. 


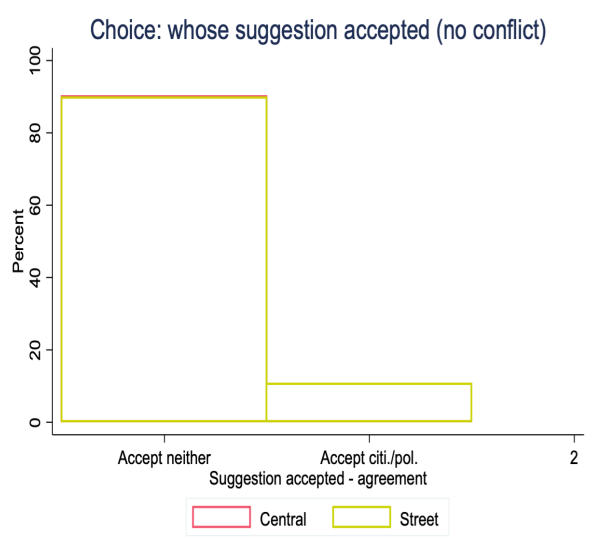

Figure 13: Choice to accept or reject proposals under no conflict

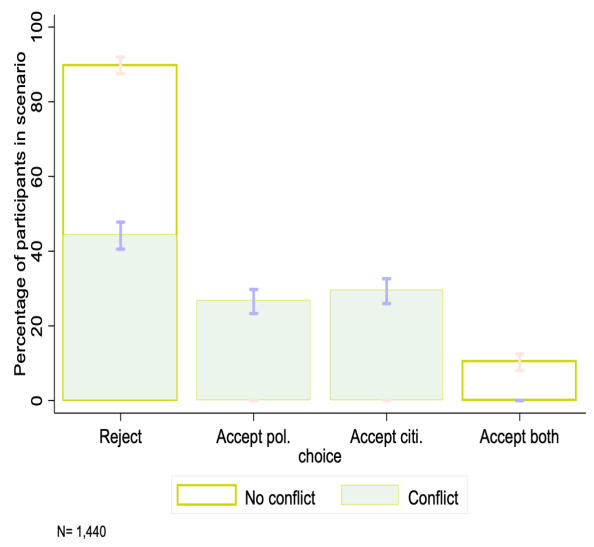

Figure 15: Choice to accept or reject proposals, under conflict and without conflict

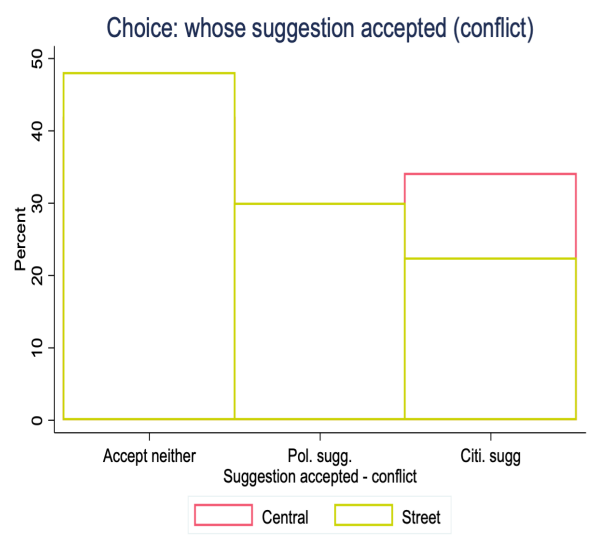

Figure 14: Choice to accept or reject proposals under conflict 


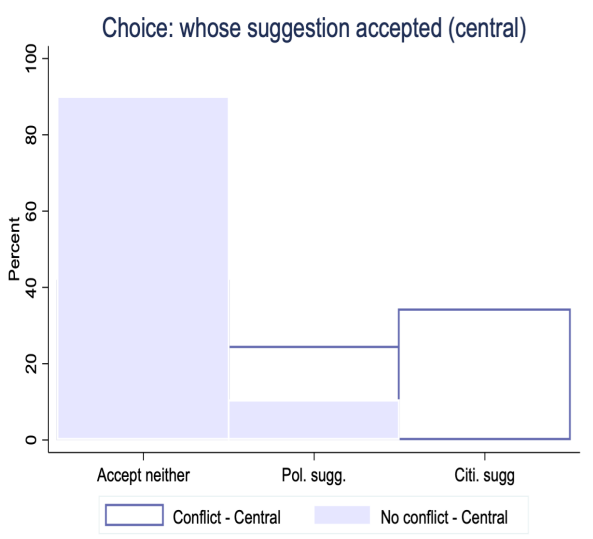

Figure 16: Choice to accept or reject proposals under no conflict of streetlevel bureaucrats

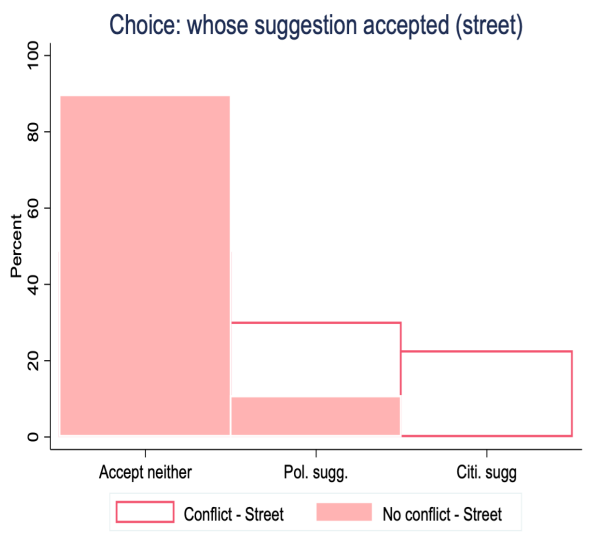

Figure 17: Choice to accept or reject proposals under no conflict of bureaucrats employed in non-street-level roles 
Table 9: Exploratory analysis: OLS regression estimating treatment effects on client-value and professionavalue conflict in response to demands from citizens and politicians

\begin{tabular}{|c|c|c|c|c|c|c|c|c|}
\hline & $\begin{array}{c}\text { (1) } \\
\text { Client-Value: Pol. } \\
\text { b/se }\end{array}$ & $\begin{array}{c}(2) \\
\text { Client-Value: Pol. } \\
\text { b/se }\end{array}$ & $\begin{array}{c}\text { (3) } \\
\text { Client-Value: Citi. } \\
\text { b/se }\end{array}$ & $\begin{array}{c}(4) \\
\text { Client-Value: Citi. } \\
\text { b/se }\end{array}$ & $\begin{array}{c}(5) \\
\text { Prof.-Value: Pol. } \\
\text { b/se }\end{array}$ & $\begin{array}{c}\text { (6) } \\
\text { Prof.-Value: Pol. } \\
\text { b/se }\end{array}$ & $\begin{array}{c}(7) \\
\text { Prof.-Value: Citi. } \\
\text { b/se }\end{array}$ & $\begin{array}{c}(8) \\
\text { Prof.-Value: Citi. } \\
\text { b/se }\end{array}$ \\
\hline Emotional & $\begin{array}{c}0.007 \\
(0.108)\end{array}$ & $\begin{array}{c}0.019 \\
(0.105)\end{array}$ & $\begin{array}{l}-0.040 \\
(0.101)\end{array}$ & $\begin{array}{l}-0.035 \\
(0.099)\end{array}$ & $\begin{array}{l}-0.032 \\
(0.109)\end{array}$ & $\begin{array}{l}-0.023 \\
(0.107)\end{array}$ & $\begin{array}{c}-0.181+ \\
(0.102)\end{array}$ & $\begin{array}{c}-0.175+ \\
(0.102)\end{array}$ \\
\hline Conflict & $\begin{array}{l}1.722^{* *} \\
(0.100)\end{array}$ & $\begin{array}{l}1.722^{* *} \\
(0.101)\end{array}$ & $\begin{array}{l}0.954^{* *} \\
(0.083)\end{array}$ & $\begin{array}{c}0.954^{* *} \\
(0.083)\end{array}$ & $\begin{array}{l}0.802^{* *} \\
(0.094)\end{array}$ & $\begin{array}{c}0.802^{* *} \\
(0.095)\end{array}$ & $\begin{array}{c}0.370^{* *} \\
(0.077)\end{array}$ & $\begin{array}{c}0.370^{* *} \\
(0.078)\end{array}$ \\
\hline Emotional $\times$ Conflict & $\begin{array}{c}0.139 \\
(0.147)\end{array}$ & $\begin{array}{c}0.139 \\
(0.148)\end{array}$ & $\begin{array}{c}-0.197+ \\
(0.109)\end{array}$ & $\begin{array}{r}-0.197+ \\
(0.110)\end{array}$ & $\begin{array}{c}0.080 \\
(0.135)\end{array}$ & $\begin{array}{c}0.080 \\
(0.135)\end{array}$ & $\begin{array}{l}0.195+ \\
(0.105)\end{array}$ & $\begin{array}{l}0.195+ \\
(0.105)\end{array}$ \\
\hline Constant & $\begin{array}{c}2.765^{* *} \\
(0.077) \\
\end{array}$ & $\begin{array}{c}3.043^{* *} \\
(0.141)\end{array}$ & $\begin{array}{c}2.681^{* *} \\
(0.073)\end{array}$ & $\begin{array}{c}2.776^{* * *} \\
(0.180) \\
\end{array}$ & $\begin{array}{c}3.024^{* *} \\
(0.080)\end{array}$ & $\begin{array}{c}3.380^{* *} \\
(0.169) \\
\end{array}$ & $\begin{array}{c}2.937^{* *} \\
(0.077) \\
\end{array}$ & $\begin{array}{c}3.139^{* * *} \\
(0.184)\end{array}$ \\
\hline Covariates added & No & Yes & No & Yes & No & Yes & No & Yes \\
\hline$R^{2}$ & 0.31 & 0.33 & 0.10 & 0.14 & 0.08 & 0.12 & 0.03 & 0.05 \\
\hline Observations & 1440 & 1440 & 1440 & 1440 & 1440 & 1440 & 1440 & 1440 \\
\hline
\end{tabular}




\section{Qualitative responses: reasoning and rationalisation of choices}

At the end of the survey experiment, bureaucrats were asked two openended questions. They were asked to explain what they considered when they made a decision in response to the presented scenarios, and second, what they thought to be barriers to responding to citizen input. About $87 \%$ of respondents answered both open-ended questions; $90 \%$ answered at least one of the two. There is no significant association between observable demographic characteristics and completion of open-ended questions apart from age. Bureaucrats aged $65+$ completed the open-ended questions at a lower rate than other age groups. However, there were only four bureaucrats in the sample who were aged $65+$. Once a control for multiple comparisons is added, this difference is no longer be statistically significant. Therefore, this difference is likely not meaningful. There is no association between treatment and demographic characteristics.

For analysis of the text responses, 300 responses are randomly sampled. Thematic analysis is used to hand-code the first 300 submissions. As one would expect from successful randomisation, these 300 submissions do not differ significantly in terms of demographic characteristics from the overall sample; they should thus act as a representative sub-sample of all demographic groups included in this survey. A second coder independently and blind to treatment conditions recoded the same 300 submissions. The percentage of codes that overlapped between coders was 91\%. The non- 
overlapping codes were harmonised following discussions with the second coder.

The ten most common themes on choice are summarised in Table 10 and for the question on perceived barriers to acting upon citizen input results are summarised in Table 11. In addition, to manual coding, the tm package in $\mathrm{R}$ is used to preprocess open-ended answers and map out key terms used in the answers against topics. Figure 18 summarises the most common words per code for the question on choice and Figure 19 for the question on barriers.

Table 10: Most common codes: choice

\begin{tabular}{lcc}
\hline \multicolumn{1}{c}{ Code } & Freq. & \%-age of sample \\
\hline Own opinion & 30 & $10.0 \%$ \\
Budget / cost & 24 & $8.0 \%$ \\
Feasibility concerns & 23 & $7.7 \%$ \\
Compromise between parties & 20 & $6.7 \%$ \\
Performance / targets / work experience & 20 & $6.7 \%$ \\
Big picture / wider society & 19 & $6.3 \%$ \\
Representativeness of input & 14 & $4.7 \%$ \\
Quality of input & 9 & $3.0 \%$ \\
Whatever citizens demand & 6 & $2.0 \%$ \\
Own expertise & 6 & $2.0 \%$ \\
\hline
\end{tabular}

To gain a better understanding of whether these themes are systematically related to demographics or choices of the participant, dummy variables for the presence/absence of each theme are created. Next, a correlation matrix of dummies for themes, demographic characteristics, the primary (willingness) and secondary outcomes (choice) is created.

Since there are more than 60 comparisons and the likelihood of false positives is high, only correlations that are significant at $\mathrm{p}<0.001$ or have a correlation coefficient that can be considered as moderate (rho $>=0.3$ ) are 
reported. Associations with demographics were only weak and none was significant at $\mathrm{p}<0.001$. The only meaningful association is that those bureaucrats who take an organisational view - their bureaucratic agency's views comes first and foremost - are less willing to support the politician's decision in a conflict scenario than bureaucrats who gave other reasons (rho=-0.27, $\mathrm{p}<0.001)$

The lack of correlation between action and reported reasons is in line with the literature on motivated reasoning. Most commonly, bureaucrats relied on their own opinion, their experiences, the values they held and the perceived need to work towards a compromise between citizen and politician demands. A substantial number of bureaucrats stated that they would put citizen opinion first when they chose a plan of action during the experiment. However, most responded with the caveat that while they put citizens' voice first they thought there were barriers that meant they could not feasibly support citizen suggestions. Indeed, 34 out of $43(79 \%)$ bureaucrats who said that they cared above all about citizens' voice, did not chose to support citizen suggestions in the conflict scenario. Instead, they made an alternative suggestion. 
Figure 18: This figure summarises the three most important (stemmed) words for each theme related to the choice made by the bureaucrat. Where there are ties between the importance of words, more than three are represented.
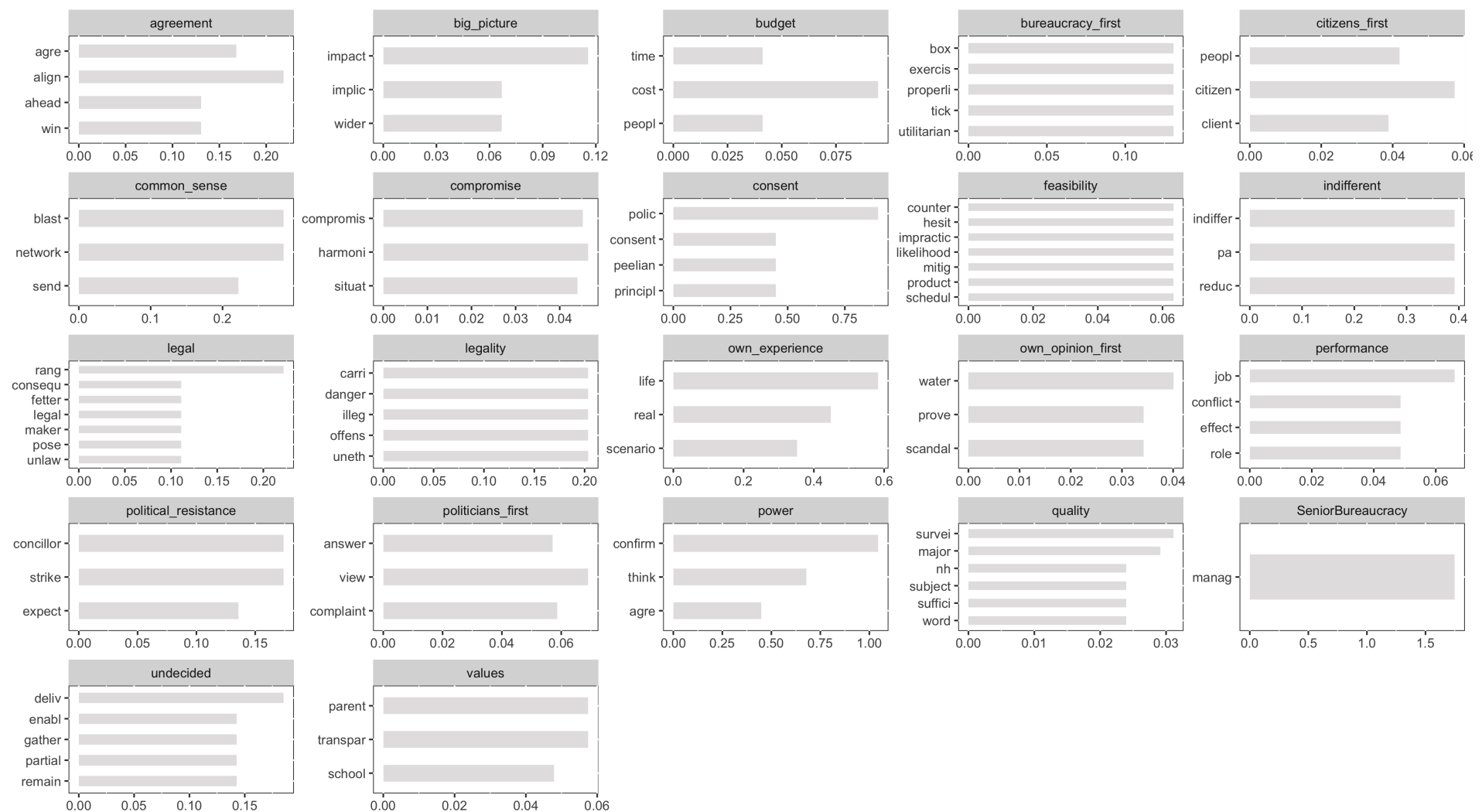
Together with budget, an underlying scepticism about the validity of citizen input was perceived as a significant barrier to acting upon citizen input. Many bureaucrats doubted whether citizen suggestions can be taken at facevalue. They insisted that citizens do not have the expertise or circumspection to suggest changes that are feasible, for their own good or for the good of society at large. For example, one bureaucrat laments:

"Citizens view our work from the outside, and only look at immediate consequences and effects. They don't always consider the practicality of some ideas. Just because government salaries are paid by taxpayers doesn't mean that the taxpayers' opinions will always be well-developed and wellresearched."

Many bureaucrats thus took a paternalistic view: they cannot act upon citizen input because citizens do not know what is best for them and what is feasible. Those bureaucrats that were somewhat more enthusiastic located barriers among the net of other stakeholders involved in policy changes. These bureaucrats pointed out that often demands from citizens, politicians and pressure groups are conflicting. Finally, a tranche of bureaucrats found that it is mostly red tape, bureaucratic processes, inertia and political resistance that impede them from acting upon citizen input. 
Table 11: Most common codes: barriers

\begin{tabular}{lcc}
\hline \multicolumn{1}{c}{ Code } & Freq. & \%-age of sample \\
\hline Lack of expertise / unqualified & 43 & $14 \%$ \\
Budget / money & 41 & $14 \%$ \\
Conflicting demands & 31 & $10 \%$ \\
Feasibility concerns & 28 & $9 \%$ \\
Time constraints & 21 & $7 \%$ \\
Lack of representativeness & 18 & $6 \%$ \\
Red tape & 16 & $5 \%$ \\
Senior bureaucracy & 15 & $5 \%$ \\
Political resistance & 14 & $5 \%$ \\
Inertia & 12 & $4 \%$ \\
\hline
\end{tabular}


Figure 19: This figure shows the three most important (stemmed) words from answers on the perceived barriers of responding to citizen input. Where there are ties between the importance of words, more than three are represented.
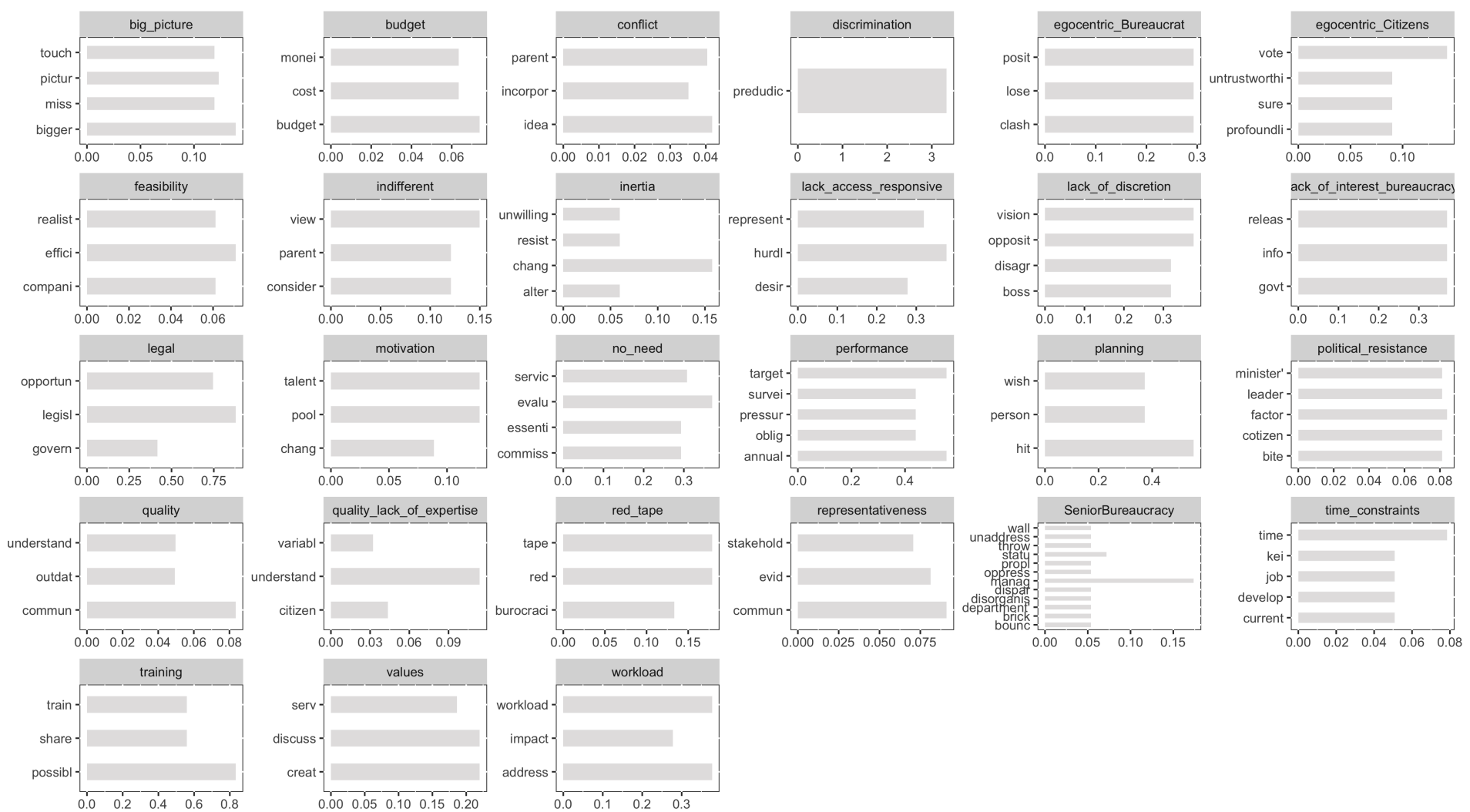


\section{Discussion}

Bureaucrats have always been "partial agents" of various governmental principals, "without being under the complete authority of any one in particular, and without any common understanding of how authority is legitimately divided among the competing principals" (Moe, 1985, pp.768-769). Adding to this confusion, bureaucrats now need to negotiate the demands of citizens supplied through government-led yet not pervasively sanctioned public participation mechanisms.

This experiment set out to test empirically how bureaucrats react to the competing demands of political principals and citizens. Further tests look at whether this behaviour is malleable to information frames, in order to gain a better understanding of how the mode of citizen input might affect the influence that citizens can yield over bureaucrat decisions.

Results show that bureaucrats resist. When citizens and politicians are in agreement, almost $90 \%$ of bureaucrats provide their own advice. Under conflict, they however become more responsive to citizens. Counter to what classic principal-agent models of bureaucrat behaviour would expect, on average, bureaucrats do not yield to politicians at a higher rate in the conflict scenario. Rather, conflict seems to activate considerations related to client orientation and professional values.

Notably, this goes counter to the idea of bureaucrats as arbiters (Miller et al., 2017; Whitford, 2010) but stresses their importance as political actors 
in their own right. Instead, it is more in line with the bureau-shaping hypothesis, according to which bureaucrats will choose policy roles over those of pure managers and implementers (Gains and John, 2010).

In terms of heterogeneity, if responsiveness is influenced by professional norms and experience, one would expect bureaucrats who are used to working on policy issues to choose an advising role (non-street-level bureaucrats) at a greater rate than those who have a service delivery role (street-level bureaucrats). Indeed that's what the data suggests: street-level bureaucrats are less responsive. The consequences of this can be particularly heightened when as proposed by theories of representative bureaucracy, the values and preferences of bureaucratic elites misalign with the populations they are employed to serve. However, willingness to respond is high across all bureaucrat groups.

In line with predictions, the effect of conflict was larger than that of information frames. This suggests that concerns raised by the literature on behavioural public administration might lead to smaller albeit perhaps not negligible bias.

The proportion of bureaucrats who yielded to citizen demands when receiving a qualitative frame was directionally higher yet statistically not distinguishable from the quantitative frame. The small effect size could be an encouraging sign for public participation. Given that governments dictate what form participation takes, it is re-assuring that the mode of citizen input does not have large effects on the responsiveness of the bureaucracy. This 
finding could also point towards bureaucrats having developed a habit of filtering or counter-acting biases that are introduced by qualitative / emotional frames compared to purely quantitative information. This might be because of different experiences with citizen consultations. For instance, many central and local governments struggle to recruit broad-based, representative samples of citizens to comment on their policy proposals. Although the intervention materials in this experiment specified that the input was indeed representative, it is plausible that real life experience dominated such knowledge.

While there is no strong heterogeneity in responses to the scenarios, it is plausible that some types of bureaucrats found some suggestions more relevant than others. The number of bureaucrats who chose not to side with either principal could thus be inflated. However, the presence of conflict still shifted behaviour. This would not be the case when bureaucrats simply dismissed the suggestions as irrelevant to their work setting. Further, qualitative responses suggested that they considered how the scenario would translate into their work context and responses were largely homogeneous.

Bureaucrats reduce their responsiveness to citizens at a lower rate than do politicians. Thus, when citizen groups voice demands in public participation processes that are at odds with those of politicians, citizens might be able to exploit the effects of conflict to their advantage.

These findings have implications for theories of representative bureaucracy and nascent frameworks for a theory of behavioural public policy. In 
absence of clear demographic or identity markers that can cast citizens or politicians as belonging to one's own group, information frames had no effect and effects were not heterogenous by demographics. line with propositions made by Meier (2018), future studies should investigate under which circumstances representative bias becomes activated and translates into differences in how bureaucrats interact with policy. Following Bertelli and Riccucci (2020)'s call for more theory development in the area of behavioural public administration, there is a strong demand for more studies contrasting bias which can be introduced by institutional mechanisms - such as how much discretion from a political principal as professionalised street-level bureaucrat has compared to someone working in a ministry - as compared to purely perceptual biases.

Some other patterns uncovered in this experiment invite further development of models and data collection. Replications could test whether the salience and type of public input changes responses. For instance, do bureaucrats react differently to referendum results compared to those from public comment or consultations? Future models could incorporate noisy signals from political principals or citizens without the need to include third players, which severely complicates the ability to find closed models. Audit experiments could assess how different directives - such as politicians' memos - affect behavioural measures of responsiveness, such as the speed at which bureaucrats process requests. They could also test the effect of aggregate versus individualised input. For example, does it matter whether bureaucrats are 
confronted with citizen input in an aggregate manner as opposed to when they evaluate single cases such as in Scott (1997) where information frames did have significant effects?

Going forward, bureaucrat behaviour should also be studied at the group level. Bureaucracies are not only hierarchical but also marked by collective decision-making. Several bureaucrats in this experiment noted that they believe senior bureaucrats are an obstacle to responding to citizen input in a meaningful way. It remains an empirical question whether influence truly acts in such a top-down manner and why senior bureaucrats might act in such a way. Finally, motivations can be further unpacked. For instance, do bureaucrats obstruct to alleviate the need for politicians to heed to citizen demands between elections or do they do so for their own benefit, to retain greater control over the policy process?

Bureaucrats will continue to shape policy design and implementation. The role this plays for the quality of democracy should remain a focal point of future academic work. 


\section{References}

Aberbach, J. D. and B. A. Rockman (1994). Civil Servants and Policymakers: Neutral or Responsive Competence? Governance 7(4), 461-469.

Adolph, C. (2013). Bankers, Bureaucrats, and Central Bank Politics : The Myth of Neutrality /Christopher Adolph. Cambridge studies in comparative politics.

Alford, J., J. Hartley, S. Yates, and O. Hughes (2017). Into the Purple Zone: Deconstructing the Politics/Administration Distinction. American Review of Public Administration 47(7), 752-763.

Andersen, S. C. and M. Jakobsen (2016). Policy Positions of Bureaucrats at the Front Lines: Are They Susceptible to Strategic Communication? $x x, 1-10$.

Andrews, R., R. Ashworth, and K. J. Meier (2014). Representative bureaucracy and fire service performance. International public management journal 17(1), $1-24$.

Arceneaux, K. (2012). Cognitive Biases and the Strength of Political Arguments. American Journal of Political Science 56(2), 271-285.

Baekgaard, M., J. Blom-Hansen, and S. Serritzlew (2015a). When Politics Matters: The Impact of Politicians' and Bureaucrats' Preferences on Salient and Nonsalient Policy Areas. Governance 28(4), 459-474.

Baekgaard, M., J. Blom-Hansen, and S. Serritzlew (2015b). When politics matters: The impact of politicians' and bureaucrats' preferences on salient and nonsalient policy areas: When politics matters. Governance (Oxford) 28(4), 459-474.

Baekgaard, M., J. Blom-Hansen, and S. Serritzlew (2020). How politicians see their relationship with top bureaucrats: Revisiting classical images. Governance.

Baekgaard, M., J. Christensen, C. M. Dahlmann, A. Mathiasen, and N. B. G. Petersen (2019). The Role of Evidence in Politics: Motivated Reasoning and Persuasion among Politicians. British Journal of Political Science 49(3), 11171140 .

Baekgaard, M. and S. Serritzlew (2020). Those who understand it will not be persuaded: A performance information paradox. International public management journal 23(1), 138-160. 
Banks, J. S. and B. R. Weingast (1992). The Political Control of Bureaucracies under Asymmetric Information. American Journal of Political Science 36(2), 509-524.

Banuri, S., S. Dercon, and V. Gauri (2018). Biased Policy Professionals. IDEAS Working Paper Series from RePEc.

Batory, A. and S. Svensson (2019). The use and abuse of participatory governance by populist governments. Policy and Politics 47(2), 227-244.

Belardinelli, P., N. Bellé, M. Sicilia, and I. Steccolini (2018). Framing Effects under Different Uses of Performance Information: An Experimental Study on Public Managers. Public Administration Review 78(6), 841-851.

Bendor, J. (2003). Herbert A. Simon: Political Scientist. Annual Review of Political Science 6, 433-471.

Bertelli, A. M. and P. John (2010). Government Checking Government: How Performance Measures Expand Distributive Politics. The Journal of Politics 72(2), $545-558$.

Bertelli, A. M. and N. M. Riccucci (2020). What is behavioral public administration good for? Public administration review.

Blom-Hansen, J., M. Baekgaard, and S. Serritzlew. How bureaucrats shape political decisions: The role of policy information. Public Administration n/a(n/a).

Brader, T., N. A. Valentino, and E. Suhay (2008). What triggers public opposition to immigration? anxiety, group cues, and immigration threat. American Journal of Political Science 52(4), 959-978.

Butler, D. M. and K. Arceneaux (2015). How Not to Increase Participation in Local Government: Th e Advantages of Experiments When Testing Policy Interventions. Public Administration Review xx, 1-36.

Chong, Dennis and James N. Druckman (2007). Framing Public Opinion in Competitive Democracies. American Political Science Review 101(4), 637-655.

Colonelli, E., E. Teso, and M. Prem (2018). Working Paper.

Costa, M. (2017). How Responsive are Political Elites? A Meta-Analysis of Experiments on Public Officials. Journal of Experimental Political Science 4(3), $241-254$. 
Cruz, C. and P. Keefer (2015). Political Parties, Clientelism, and Bureaucratic Reform. Comparative Political Studies 48(14), 1942-1973.

Donovan, K., P. M. Kellstedt, E. M. Key, and M. J. Lebo (2019). Motivated Reasoning, Public Opinion, and Presidential Approval. Political Behavior (0123456789).

Druckman, J. (2001). The Implications of Framing Effects for Citizen Competence. Political Behavior 23(3), 225-256.

Druckman, J. N. (2004). Political preference formation: Competition, deliberation, and the (ir)relevance of framing effects. American Political Science Review $98(4), 671$.

Druckman, J. N. and R. McDermott (2008). Emotion and the framing of risky choice. Political Behavior 30(3), 297-321.

Emeriau, M. (2019). Learning to be Unbiased: Evidence from the French Asylum Office. Working Paper.

Enikolopov, R. (2014). Politicians, bureaucrats and targeted redistribution. Journal of Public Economics.

Esteve, M., C. Schuster, A. Albareda, and C. Losada (2017). The Effects of Doing More with Less in the Public Sector: Evidence from a Large-Scale Survey. Public Administration Review 77(4), 544-553.

Fishkin, J. S. (2018). Democracy when the people are thinking: Revitalizing our politics through public deliberation. Number November 2019.

Fox, J. and K. W. Shotts (2009). Delegates or trustees? A theory of political accountability. Journal of Politics 71 (4), 1225-1237.

Fung, Archon; Wright, E. O. (2001). Deepening Democracy: Innovations in Empowered Participatory Governance. Politics and Society 29(1), 5-41.

Gailmard, S. and J. W. Patty (2012). Formal models of bureaucracy. Annual review of political science 15(1), 353-377.

Gains, F. and P. John (2010). What do bureaucrats like doing? Bureaucratic preferences in response to institutional reform. Public Administration Review 70(3), $455-463$. 
Gains, F., P. John, and G. Stoker (2008). When do bureaucrats prefer strong political principals? institutional reform and bureaucratic preferences in english local government. British journal of politics international relations 10(4), 649665.

Hartman, T. and C. Weber (2009). Who Said What? The Effects of Source Cues in Issue Frames Author ( $\mathrm{s}$ ): Todd K . Hartman and Christopher R . Weber Published by : Springer Stable URL : http://www.jstor.org/stable/40587298 Accessed : 10-05-2016 11 : 03 UTC. Political Behavior 31(4), pp. 537-558.

Hustedt, T. and H. H. Salomonsen (2014). Ensuring political responsiveness: politicization mechanisms in ministerial bureaucracies. International Review of Administrative Sciences 80(4), 746-765.

Kahneman, D. and A. Tversky (1984). Choices, values, and frames. American Psychologist 39(4), 341-350.

Keiser, L. R. (2010). Understanding street-level bureaucrats' decision making: Determining eligibility in the social security disability program. Public administration review 70 (2), 247-257.

Keiser, L. R., V. M. Wilkins, K. J. Meier, and C. A. Holland (2002). Lipstick and logarithms: Gender, institutional context, and representative bureaucracy. The American political science review 96(3), 553-564.

Lau, R. R. and M. Schlesinger (2005). Policy Frames, Metaphorical Reasoning, and Support for Public Policies. Political Psychology 26(1), 77-114.

Lipsky, M. (1983). Street-Level Bureaucracy The Dilemmas of the Individual in Public Service. Publications of Russell Sage Foundation Street-level bureaucracy. New York: Russell Sage Foundation.

Már, K. and J. Gastil (2019). Tracing the Boundaries of Motivated Reasoning: How Deliberative Minipublics Can Improve Voter Knowledge. Political Psychology $0(0), 1-21$.

Meier, K. J. (2018, 06). Theoretical Frontiers in Representative Bureaucracy: New Directions for Research. Perspectives on Public Management and Governance 2(1), 39-56.

Meyer-Sahling, J.-H., K. S. Mikkelsen, and C. Schuster (2018). Civil service management and corruption: What we know and what we don't. Public Administration 96(2), 276-285. 
Migchelbrink, K. and S. Van De Walle (2020). When will public officials listen? a vignette experiment on the effects of input legitimacy on public officials' willingness to use public participation. Public Administration Review 80(2), 271-280.

Miller, P., R. Reynolds, and M. Singer (2017). Mobilizing the young vote: Direct mail voter guides in the 2015 Chicago mayoral election. Research and Politics $4(4)$.

Moe, T. M. (1985). Control and feedback in economic regulation: The case of the nlrb. The American Political Science Review 79(4), 1094-1116.

Moe, T. M. (2006). Political control and the power of the agent. Journal of Law, Economics, and Organization 22(1), 1-29.

Moe, T. M. (2012). Delegation, control, and the study of public bureaucracy. The Forum 10(2).

Newman, B. and J. D. Griffin (2005). Are Voters Better Represented? Journal of Politics 67(4), 1206-1227.

Nicholson-Crotty, S. and L. J. O'Toole (2004). Public management and organizational performance: The case of law enforcement agencies. 14(1), 1-18.

Nuñez, N., K. Schweitzer, C. A. Chai, and B. Myers (2015). Negative Emotions Felt During Trial: The Effect of Fear, Anger, and Sadness on Juror Decision Making. Applied Cognitive Psychology 29(2), 200-209.

Nyhan, B. and J. Reifler (2010). When corrections fail: The persistence of political misperceptions. Political Behavior 32(2), 303-330.

OECD (2009). Focus on Citizens - Public engagement for Better Policy and Services.

Olsen, A. L. (2013). Leftmost-digit-bias in an enumerated public sector? An experiment on citizens' judgment of performance information. Judgment and Decision Making 8(3), 365-371.

Olsen, A. L. (2015). Citizen (Dis)satisfaction: An experimental equivalence framing study. Public Administration Review 75(3), 469-478.

Page, E. C. (2012). Policy Without Politicians: Bureaucratic Influence in Comparative Perspective. Oxford: Oxford University Press. 
Palan, S. and C. Schitter (2018). Prolific.ac - A subject pool for online experiments. Journal of Behavioral and Experimental Finance 17, 22-27.

Peer, E., L. Brandimarte, S. Samat, and A. Acquisti (2017). Beyond the Turk: Alternative platforms for crowdsourcing behavioral research. Journal of Experimental Social Psychology 70, 153-163.

Petrova, D. G., J. Van der Pligt, and R. Garcia-Retamero (2014). Feeling the numbers: On the interplay between risk, affect, and numeracy. Journal of Behavioral Decision Making 27(3), 191-199.

Prendergast, C. (2007). The motivation and bias of bureaucrats. American Economic Review 97(1), 180-196.

Raaphorst, N. and S. Van de Walle (2017). A signaling perspective on bureaucratic encounters: How public officials interpret signals and cues. Social Policy 86 Administration (August 2016), 1-12.

Redlawsk, D. P. (2002). Hot Cognition or Cool Consideration? Testing the Effects of Motivated Reasoning on Political Decision Making. Journal of Politics 64(4), 1021-1044.

Rottenstreich, Y. and C. K. Hsee (2001). Money , Kisses, and Electric Shocks : On the Affective Psychology of Risk Author ( $\mathrm{s}$ ): Yuval Rottenstreich and Christopher K . Hsee Published by : Sage Publications, Inc . on behalf of the Association for Psychological Science Stable URL : http://www.j. Psychological Science 12(3), 185-190.

Rottinghaus, B. (2015). Rethinking Presidential Responsiveness : The Public. The Journal of Politics 68(3), 720-732.

Scott, P. G. (1997, jan). Assessing Determinants of Bureaucratic Discretion: An Experiment in Street-Level Decision Making. Journal of Public Administration Research and Theory 7(1), 35-58.

Speer, J. (2012). Participatory Governance Reform: A Good Strategy for Increasing Government Responsiveness and Improving Public Services? World Development 40(12), 2379-2398.

Ting, M. M. (2001). The "Power of the purse" and its implications for bureaucratic policy-making. Public Choice 106(3-4), 243-274. 
Tracy, J. L. and D. Randles (2011). Four models of basic emotions: A review of ekman and cordaro, izard, levenson, and panksepp and watt. Emotion Review 3(4), 397-405.

Tummers, L., B. Vermeeren, B. Steijn, and V. Bekkers (2012). Public professionals and policy implementation. Public Management Review 14(8), 1041-1059.

Walgrave, S., J. Sevenans, K. Van Camp, and P. Loewen (2018). What Draws Politicians' Attention? An Experimental Study of Issue Framing and its Effect on Individual Political Elites. Political Behavior 40(3), 547-569.

Whitford, A. B. (2010). The Pursuit of Political Control by Multiple Principals The Pursuit of Political Control by Multiple Principals. Control 67(1), 29-49. 


\section{Appendix I: Survey questions}

A few questions on the above...

1. To what extent are you willing or unwilling to support changes suggested by your [political principal]?

[7] Absolutely willing

[6] Very much willing

[5] Somewhat willing

[4] Neither willing nor unwilling

[3] Somewhat unwilling

[2] Very much unwilling

[1] Absolutely unwilling

2. To what extent are you willing or unwilling to support changes suggested by your citizen group?

[7] Absolutely willing

[6] Very much willing

[5] Somewhat willing

[4] Neither willing nor unwilling

[3] Somewhat unwilling

[2] Very much unwilling

[1] Absolutely unwilling

3. Imagine you are now asked by the head of your team to choose a strategy based on the two opinions presented. Which one would you choose?

In a conflict scenario

ward.

[1] I would suggest to implement what the citizen group put forforward.

[2] I would suggest to implement what [political principal] put thing else.

[3] I would accept neither of their suggestions but suggest some-

In a non-conflict scenario 
[1] I would suggest to implement what the citizen group and [political principal] put forward.

[2] I would accept neither of their suggestions but suggest something else.

Now, we would like to ask a few questions about how you feel about the suggestions made by the [political principal]. [Professional-value conflict: item 1]

4. Please rate to what extent you agree or disagree with the following statement The changes suggested by the [political principal] conflict with my values and norms as a professional [7] Totally agree

[6] Agree mostly

[5] Agree somewhat

[4] Neither agree nor disagree

[3] Disagree somewhat

[2] Disagree mostly

[1] Totally disagree

5. Please rate to what extent you agree or disagree with the following statement The changes suggested by the [political principal] would negatively affect my professional autonomy

[7] Totally agree

[6] Agree mostly

[5] Agree somewhat

[4] Neither agree nor disagree

[3] Disagree somewhat

[2] Disagree mostly

[1] Totally disagree

6. Please rate to what extent you agree or disagree with the following statement The changes suggested by the [political principal] would clash with the wishes of many of my clients (citizens affected by my work)

[7] Totally agree

[6] Agree mostly

[5] Agree somewhat 
[4] Neither agree nor disagree

[3] Disagree somewhat

[2] Disagree mostly

[1] Totally disagree

7. Please rate to what extent you agree or disagree with the following statement My clients (citizens affected by my work) would perceive the changes suggested by the [political principal] as wasteful

[7] Totally agree

[6] Agree mostly

[5] Agree somewhat

[4] Neither agree nor disagree

[3] Disagree somewhat

[2] Disagree mostly

[1] Totally disagree

Next, could you tell us next how you feel about the suggestions made by the citizen group?

8. Please rate to what extent you agree or disagree with the following statement The changes suggested by the citizen group conflict with my values and norms as a professional

[7] Totally agree

[6] Agree mostly

[5] Agree somewhat

[4] Neither agree nor disagree

[3] Disagree somewhat

[2] Disagree mostly

[1] Totally disagree

9. Please rate to what extent you agree or disagree with the following statement The changes suggested by the citizen group would negatively affect my professional autonomy

[7] Totally agree

[6] Agree mostly 
[5] Agree somewhat

[4] Neither agree nor disagree

[3] Disagree somewhat

[2] Disagree mostly

[1] Totally disagree

10. Please rate to what extent you agree or disagree with the following statement The changes suggested by the citizen group would clash with the wishes of many clients (citizens affected by my work)

[7] Totally agree

[6] Agree mostly

[5] Agree somewhat

[4] Neither agree nor disagree

[3] Disagree somewhat

[2] Disagree mostly

[1] Totally disagree

11. Please rate to what extent you agree or disagree with the following statement My clients (citizens affected by my work) would perceive the changes suggested by the citizen group as wasteful

[7] Totally agree

[6] Agree mostly

[5] Agree somewhat

[4] Neither agree nor disagree

[3] Disagree somewhat

[2] Disagree mostly

[1] Totally disagree 


\section{Appendix II - Pilot: additional information}

Each participant received 6 vignettes: (a) positively phrased and quantitative information, (b) negatively phrased and quantitative information, (c) positively phrased and emotive/qualitative information, (d) positively phrased and emotive/qualitative information, (e) a mix of quantitative and emotive information and positive phrasing, (f) a mix of quantitative and emotive information and negative phrasing. 


\section{Appendix III: Overview of terms and contexts}

Table 12: Terms used to refer to government and public sector organisations

\begin{tabular}{ll}
\hline US term & UK term \\
\hline Local government (e.g. county, town, city, municipality) & Local government authority \\
State government & Government department \\
Federal government / Federal agency & Regulator \\
Regulator & Front line services (e.g. NHS, education, police, TfL) \\
State owned or run services (e.g. public schools, parks, Amtrak)
\end{tabular}

